\title{
Finance-Growth Nexus and Relative Efficacy of Alternative Policy Regimes: An Investigation for Pakistan
}

\author{
Saira Tufail and Ather Maqsood Ahmed ${ }^{1}$
}

\begin{abstract}
The recurring financial turbulences, witnessed in both advanced and emerging economies over the past few decades, have brought financial stability risks and potential monetary and macro-prudential policies in addressing them, to the forefront of policy debates. This study assesses the nature of finance-growth relationship to address some of the long-standing and recent issues in the conduct of monetary policy. Specifically, it addresses three research questions, that are; 1) Does the traditional finance-growth relationship exist for EDEs? 2) Should benign neglect or lean against the wind be the central bank strategy for stabilizing macroeconomic shocks? and, 3) Does macro-prudential policy present policy dilemma or boosts economic growth by addressing financial vulnerabilities efficiently? By estimating DSGE model using Bayesian technique for Pakistan the findings of the study showed the segregation of financial and business cycle activities and the absence of most trumpeted credit-growth nexus for Pakistan. Given growth is not credit driven, financial instability concerns emanating from credit boom and bust cycles in developed countries become irrelevant for financially less developed EDEs like Pakistan. Price and financial stability goals of central bank are not found dichotomous conforming to Jackson Hole Consensus; a monetary policy strategy prevalent before GFC. Overall findings of study suggest that monetary authority may reconsider its commitment for implementing Basel III and other macro-prudential regulations to counter the risk of over regulation and to boost the process of benign financial deepening.
\end{abstract}

Keywords: Monetary Policy, Macro-prudential Policy, Estimated DSGE, Lean versus Clean, Jackson Hole Consensus, Basel III

JEL Classification: E58, G18, G17

\section{Introduction}

The recurring financial turbulences, witnessed in both advanced and emerging economies over the past few decades, have brought financial stability

1 The authors are PhD Scholar and Professor \& Head, Department of Economics, School of Social Sciences and Humanities, National University of Science and Technology, Islamabad, respectively. Corresponding author's email: sairatufail@s3h.nust.edu.pk. 
risks and potential monetary and macro-prudential policies in addressing them, to the forefront of policy debates.

In the period of great moderation, aggressive inflation targeting was largely considered sufficient for both price and financial stability, with monetary policy being passive to financial stability concerns- the strategy popularly known as benign neglect or the Jackson Hole consensus. ${ }^{2}$ The global financial crises (GFC) raised concerns about the validity of the Jackson Hole consensus as asserted by Gali and Gambetti (2015), and strengthened the debate for 'leaning against the wind' with growing empirical ratification. ${ }^{3}$ Monetary policy debate in this regard seems to approach a general agreement, that central bank should be allowed to lean against the wind in the build-up of systematic risks, while keeping price stability over the medium term as its primary objective. ${ }^{4}$

On the other hand, empirical evidences on the effectiveness of macroprudential policies are still preliminary and inconclusive. Despite this, an increasing number of endorsement to Basel III accord and other financial regulations are largely observed in policy practices to control credit growth, particularly for emerging and developing economies (EDEs) (See, Figure 1 in Appendix A). This prudence is due to the ample evidence regarding strong ex-ante correlation between credit booms and likelihood of systematic risk reported in the empirical literature analyzing the historical and cross-country episodes of financial crises (Mendoza and Terrones, 2008 and Dell'Ariccia et al., 2012).

Nonetheless, neither all countries are financially vulnerable nor all credit booms prelude financial crises. ${ }^{5}$ A large number of EDEs are marginally penetrated in global financial markets as Cerutti et al. (2015) reported that many emerging and

\footnotetext{
${ }^{2}$ The justification of this view, comprising empirical backing, is provided by Bernanke and Gertler (2001), Greenspan (2002), Gilchrist and Leahy (2002) and Svensson (2010,2012), among others. Financial misalignments are disregarded on the basis of reasons that they are not identified easily and are measured in real time. Moreover, it is also alleged that monetary policy do deals with asset price bubbles but with detrimental costs to the economy. Furthermore targeting financial vulnerabilities raises moral hazard problem and causes indeterminacy of inflation.

${ }^{3}$ See, for instance, Cerra and Saxena, (2008); Curdia and Woodford, (2009a; 2009b); Reinhart and Rogoff (2009); and Smets, (2014.)

${ }^{4}$ Mishkin (2011) and Woodford (2012) implied that it is appropriate for monetary policy to lean against a credit boom, even if central bank has to compromise on a lower medium-term target for both inflation and the output gap.

${ }^{5}$ For instance, China, India, Pakistan and Bangladesh have limited exposure to foreign currency denominated assets due to capital controls and partial capital convertibility.
} 
almost all developing countries financially closed. ${ }^{6}$ Chinn (2015) index of financial openness also reveals startling differences in the financial characteristics of advanced and EDEs (see Figure 2 in appendix A). Moreover, Levine (2012) conjectured that mismatch between dynamic pace of financial sector and financial regulation that failed to keep pace with the process of financial innovations ruined financial system. ${ }^{7}$ However, the implementation of financial regulation in emerging economies is well ahead of the sluggish process of financial innovations. It bears no surprise that many of these countries were largely spared of the financial repercussions of GFC. ${ }^{8}$

Similarly, Tornell and Westermann (2002) showed that not all credit booms anchor excessive risk taking and could be reflective of more benign financial deepening. The EDEs experienced the least likelihood of a credit boom during 1960-2017 (Meng and Gonzalez, 2017) with a higher average magnitude of booms but rare prevalence (12 percent) of banking crises as compared to advanced economies (50 percent). More importantly, Gourinchas et al. (2001) pointed out that credit booms not preceded by financial crises enhanced financial deepening whose proportion as calculated by Arena et al. (2015) is 63 to 70 percent for developing countries. This finding may sound appealing for many EDEs, which could not register significant gains in terms of approaching their benchmark financial possibility frontier and require market enabling polices that trigger financial depth (Barajas et al. 2013). In such situation, impeding credit growth may come with a considerable cost of drifting further away from benchmark financial possibility frontier, incising benefits from possible financial deepening and long term economic growth (Boar et al., 2017).

Taken together, in an environment characterized with considerable financial regulations, accompanied with level of financial depth (See Figure 3 in Appendix A) inadequate to have financially inclusive growth and meagre likelihood of systematic risks it becomes imperative to reinvestigate the finance-growth nexus and the effectiveness of different monetary policy stances based on this nexus. Our

\footnotetext{
${ }^{6}$ Based on updated version of Lane and Milesi-Ferreitti (2007) dataset, a country is considered financially closed if its median openness score over 2000-2011 is less than the median of the median score for all countries in sample.

${ }^{7}$ Financial innovations include among others securitization, collateralized debt obligations and credit default swaps

${ }^{8}$ Goldstein, et al. (2009) found that the financial impact of global financial crises was less severe for Asia. Blanchard et al. (2010) also found for emerging economies, the effect of global financial crises was manageable. Park and Mercado (2014) showed that developing countries could not remain immune to the trade and growth effect of global financial crises.
} 
basic hypothesis is to check whether the nature of finance growth nexus in EDEs is similar to one existing in advanced economies. If it is same then concerns raised by GFC regarding financial stability are valid for EDEs also. Consequently, monetary policy should target both price and financial stability. Specifically the study addresses following research questions:

1. Does the traditional finance-growth relationship exist for EDEs?

2. Should benign neglect or lean against the wind be the central bank strategy for stabilizing macroeconomic shocks?

3. Does macro-prudential policy present policy dilemma or boosts economic growth by addressing financial vulnerabilities efficiently?

Our study addresses these questions considering the aforementioned financial characteristics of EDEs. In this context, we select Pakistan being an intriguing case study in a number of ways. For instance, the country is one at the bottom of financially closed economies, has decreasing level of financial development and credit growth (see figure 4 in appendix A), and has highest number of macro-prudential measures not only in the region but also ranked higher than many East Asian and Latin American countries (see figure 5 in appendix A). The country with unpenetrated financial markets has financial institutions whose efficiency is at par with many advanced and EDEs (despite erosion in last few years). This makes the case even more interesting particularly to examine the tradeoff between the pursuit of efficiency and the risks of over-regulation.

This paper addresses the aforementioned research questions in spirit of Bailliu et al. (2015) and compares the effectiveness of a policy regime focused on price stability to another where policy-makers also pursue financial stability. Setting mitigating role of different policy regimes in face of different shocks as a benchmark, our framework allows us to compare the policy regime with Taylor rule with those where monetary policy leans against the wind or is coupled with macroprudential rule. Macro-prudential rule responds counter-cyclically to credit expansion through its influence on the funding cost of firms via price of loans (that is, external finance premium). Though easily tractable, this mechanism is very useful to capture the effects of more intricate macro-prudential instruments like loan-to-value ratios and counter cyclical capital buffer, the key regulations proposed in the Basel III accord endorsed by many emerging economies.

The study addresses the research questions in framework of DSGE model using quarterly data from 1972Q1 to 2017QIV. Methodologically, our study is not the first of its kind to handle these questions. A number of studies, for instance, Kannan et al. (2012), Angelini et al. (2012), Christensen et al. (2011), Benes and 
Kumhof (2011), Quint and Rabanal (2014), Rubio and Carrasco-Gallego (2014), to name a few, have also approached these issues. However, it contributes to existing literature particularly for Pakistan in a number of ways. Finance-growth nexus has already been examined in Pakistan for the level of financial development and economic growth. For instance, Khan and Qayyum (2007), Jalil and Feridun (2011) and Khan et al., (2018) found long run positive relationship between financial development and economic growth. Though using different methodologies, all these studies have focused on the causal relationship between some indicator of financial development and economic growth. But our methodology allows us to examine this nexus over the business cycle. Instead of determining a direct relationship between financial development and economic growth this study examines the co-movement of financial and economic cycles in face of multiple favorable (like positive productivity shock, investment efficiency shock) and adverse shocks (like contractionary monetary and cost push shocks).

Secondly, along with different nominal and real shocks, the co-movement of economic and financial cycles is also examined for financial shocks. Thirdly, finance-growth nexus has been examined for Pakistan without incorporating financial market conditions. In this study the nexus is examined for both situations one where financial markets are complete and second, incorporating financial rigidities depicting financial market conditions. Moreover, the study provides the case of a particular monetary policy stance on the basis of nature of finance-growth nexus existing in the country.

Generally, for EDEs this study also contributes significantly as existing literature include studies carried out for countries that have developed financial markets and high likelihood of build-up of systematic risk. Consequently, theoretical and policy insights from these studies cannot be ipso facto applied to EDEs with under penetrated financial markets. Yet adhering to the financial strategy proposed for advanced and/or crises-hit countries due to lack of specific evidence, EDEs may stifle growth momentum associated with credit expansion, may limit the process of financial inclusion and innovation, and/or may enable the market players to evade regulations and trail alternatives that are less desirable. Moreover, we estimate the main behavioral parameters employing Bayesian estimation technique, which is quite a rare exercise for EDEs. Consequently, in addition to being relevant to Pakistan, our results may also provide insights into the interfaces between monetary and macro-prudential policies in other EDEs sharing similar features and striving for a policy-mix required to maintain a healthy balance between financial stability, growth and financial outreach. 
The rest of the study is organized as follows. Section 2 presents the log-linearized version of model. Results and discussion are presented in section 3 and section 4 concludes.

\section{Methodology}

To examine the macroeconomic dynamics and interconnections of different policy regimes, we use DSGE model that accounts for financial frictions a la Bernanke et al. (1999) and hosts four financial shocks. In the model, financial and credit conditions are pivotal in the transmission of cyclical fluctuations because of a financial accelerator mechanism. The choice of model is based on the evidence from our earlier paper where model with financial accelerator is found superior to the state-of-art DSGE models to match the observed macroeconomic fluctuations in Pakistan. Moreover, the paper also underscores certain important feedbacks from financial sector to the real economy strengthening the case for the use of the model.

As reported by Bernanke et al. (1999), financial accelerator mechanism operates through external finance premium (EFP) which is inversely related to the net worth of the firm. Hence, our model economy treats four types of shocks as financial shocks. A direct shock to EFP and a macro-prudential policy shock that channel to the economy through their bearing on EFP. While a direct shock to net worth and price of capital shock operate through firm's balance sheet and affects the funding cost of firm and aggregate economic activity. ${ }^{9}$ By including a macroprudential policy shock, transmission mechanism of macro-prudential regulation is also assessed in the model economy.

The model economy has three types of agents: households, final and intermediate good producers, and a monetary and macro-prudential authority. The model incorporates a variety of nominal and real rigidities, such as accumulation of habit stock by households, investment adjustment costs, variable capital utilization and staggered price and wage rigidities in Calvo-style, along with incomplete indexation. The model has state-of-the-art features; hence, we refrain from a detailed account of first principles and present the log-linearized version of model.

\subsection{The Model}

Expected lifetime utility of representative household is maximized given a CRRA utility function with separable preferences for consumption $\left(C_{t}\right)$ and

\footnotetext{
${ }^{9}$ Price of capital shock is considered an indirect financial shock in Smets and Wouters (2003).
} 
working hours $\left(N_{t}\right) .{ }^{10}$ Inter-temporal substitution in consumption and intratemporal trade-off between consumption and working hours gives rise to aggregate consumption that evolve around past $\left(C_{t-1}\right)$ and future consumption $\left(C_{t+1}\right)$, real interest rate $\left(r_{t}-\pi_{t+1}\right)$. Inter-temporal elasticity of substitution $\theta_{c}$ and habit persistence $(h)$ determines the extent to which consumption responds to interest rate. ${ }^{11}$ The Euler equation for consumption is given as follows.

$c_{t}=\frac{h}{1+h} c_{t-1}+\frac{1}{1+h} c_{t+1}-\frac{1-h}{1+h \theta_{c}}\left(r_{t}-\pi_{t+1}\right)+\frac{1-h}{1+h \theta_{c}}\left(\epsilon_{t}^{b}-\epsilon_{t+1}^{b}\right)$

Household consumption behaviour is also subject to a preference shock $\epsilon_{t}^{b}$.

$\epsilon_{t}^{b}=\rho_{\epsilon^{b}} * \epsilon_{t-1}^{b}+\varepsilon_{t}^{b}$ where $\varepsilon_{t}^{b} \sim$ i.i.d. $N\left(0, \sigma_{\varepsilon^{b}}^{2}\right)$ and $\rho_{\epsilon^{b}}$ is coefficient of autocovariance in exogenous $\mathrm{AR}(1)$ process defining the shock.

Households supply differentiated labor to intermediate good producer and set wages under staggered contracts with constant (Calvo) probability $\left(1-\xi_{w}\right)$ of renegotiation in each period. A fraction of households that optimize, set wages a mark-up $\mu_{t}^{w}$ over marginal rate of substitution between leisure and consumption $m r s_{t}$. Symbolically,

$$
\mu_{t}^{w}=w_{t}-m r s_{t}
$$

The wages for the remaining households are incompletely indexed with inflation parameterized through $\iota_{w}$. The combination of non-reoptimized wages and partial indexation results in the following wage equation.

$w_{t}=\frac{\beta}{1+\beta} w_{t+1}+\frac{1}{1+\beta} w_{t-1}+\frac{\beta}{1+\beta} \pi_{t+1}-\frac{1+\beta \iota_{w}}{1+\beta} \pi_{t}+\frac{\iota_{w}}{1+\beta} \pi_{t-1}-$ $\frac{1}{1+\beta \iota_{w}} \frac{1-\beta \xi_{w}\left(1-\xi_{w}\right)}{\xi_{w}\left(\phi_{w}-1\right) \varepsilon_{w}+1} \mu_{t}^{w}+\epsilon_{t}^{w}$

$\epsilon_{t}^{w}=\rho_{\epsilon^{w}} * \epsilon_{t-1}^{w}+\varepsilon_{t}^{w}$ where $\varepsilon_{t}^{w} \sim$ i.i.d.N $N\left(0, \sigma_{\varepsilon^{w}}^{2}\right)$ and $\rho_{\epsilon^{w}}$ is coefficient of autocovariance in exogenous AR(1) process defining the shock.

Equation (3) shows that real wage is a weighted average of past and expected future wages and past, current and expected inflation rate along with wage mark-up and a cost-push shock to wages $\epsilon_{t}^{w}$. The indexation of non-reoptimized wages $\iota_{w}$ determines the strength of relationship between current wages and current

\footnotetext{
${ }^{10}$ In log-linearized form of model, these variables will appear in small letters.

${ }^{11}$ Habit persistence determines the degree of consumption persistence and preference shock is a shock to discount factor that effects intertemporal substitution decisions.
} 
and past inflation whereas $\phi_{w}$ is the deviation of actual wages from wages that would have prevailed given the fully flexible labor market. ${ }^{12}$

Evolution of optimal investment trajectory specified in a dynamic Euler equation for investment is derived under the assumption that capital producer produce new capital stock $K_{t}$ in the competitive market and rent it out to entrepreneurs/ intermediate goods producers at a given rental rate of $r^{k}$. Supply of capital rental services $K_{t}^{S}$ is determined as a result of maximization problem of capital producer either by investing in additional capital $I_{t}$ or by changing the utilization rate $z_{t}$ of already installed capital. Capital goods producer incur quadratic capital adjustment $\operatorname{cost} \varphi$ for both of their actions. Investment responds sluggishly to different shocks due to costs for adjusting capital and directly affects the price of capital. Capital price is unit without capital adjustment costs. Therefore, capital adjustment costs permit the capital price to fluctuate, which contributes to impulsiveness of net worth of entrepreneurs.

Investment equation is given as follows.

$$
i_{t}=\frac{1}{1+\beta} i_{t-1}+\frac{\beta}{1+\beta} i_{t+1}+\frac{\varphi}{1+\beta} q_{t}+\beta \epsilon_{t+1}^{i}-\epsilon_{t}^{i}
$$

$\epsilon_{t}^{i}=\rho_{\epsilon^{i}} * \epsilon_{t-1}^{i}+\varepsilon_{t}^{i} \quad$ where $\varepsilon_{t}^{i} \sim i . i . d . N\left(0, \sigma_{\varepsilon^{i}}^{2}\right)$ and $\rho_{\epsilon^{i}}$ as coefficient of autocovariance in exogenous $\operatorname{AR}(1)$ process.

Similar to consumption, current investment $i_{t}$ is weighted average of past $i_{t-1}$ and expected future investment $i_{t+1}$, and value of installed capital $q_{t}$. Investment is also subject to shock $\epsilon_{t}^{I}$ which is innovation to efficiency with which consumer goods are converted into capital goods. Evolution of capital stock is depicted by standard capital accumulation equation as follows.

$$
k_{t}=(1-\delta) k_{t-1}+\delta i_{t}
$$

Where $\delta$ is depreciation cost and equation 3 determines the aggregate supply of capital in the economy. Capital expenditure $q_{t} K_{t}$ are partly financed by entrepreneurial net worth, $n w_{t}$ and partly by issuing nominal debt $b_{t}$. A financial market imperfection resulting from information asymmetries between the lender and the borrower ${ }^{13}$ entails that lender has to bear a monetary cost to observe the output. This costly state verification problem between entrepreneur and financial

\footnotetext{
12 The parameter determines the degree of wage rigidity in labor market. Higher the value of parameter lower is the difference.

13 The idiosyncratic shock is that information which is observed by the entrepreneur only and is not observed by the lender.
} 
intermediary implies that entrepreneurs face $\mathrm{EFP} s_{t}$. The risk premium on external funds, defined as entrepreneur's cost of external funds relative to the cost of internal funds creates a wedge between the expected return on $r^{k}{ }_{t+1}$ capital and risk-free rate $r_{t}$.

The capital arbitrage conditions for entrepreneur under financial friction and resultant equation for external finance premium are given as follows.

$$
\begin{aligned}
& r^{k}{ }_{t+1}=\left[\frac{1-\delta}{1-\delta+\overline{r^{k}}}\right] q_{t+1}+\left[\frac{\overline{r^{k}}}{1-\delta+\overline{r^{k}}}\right] m p k_{t+1}-q_{t} \\
& s_{t}=r^{k}{ }_{t+1}-\left(r_{t}-\pi_{t+1}\right)
\end{aligned}
$$

The $r_{t+1}^{k}$ is future rate of return on capital and in equilibrium it is equal to the cost of external funds in equilibrium while $r_{t}-\pi_{t+1}$ is the cost of internal fund. Equation 6 shows that expected return on capital between two time periods depends on expected marginal product of capital, $m p k_{t+1}$ and capital gain $q_{t+1}$. Rearranging equation 7 and expressing in terms of $r_{t+1}^{k}$ gives the supply curve or expected marginal cost curve for external financing. Under optimal contract $s_{t}$ is cyclical, that is, it increases with firm's leverage and is inversely related to the strength of entrepreneurial balance sheet. At aggregate level, it can be characterized by the following equation.

$$
s_{t}=-\chi\left(n w_{t}-q_{t}-k_{t}\right)+\epsilon_{t}^{f d}
$$

Where parameter $\chi$ measures the elasticity of EFP to variation in entrepreneurial balance sheet, measured by net worth as ratio to capital expenditures. ${ }^{14}$ Equation 8 shows that EFP determined by the size of borrower's equity in investment project. The EFP is also subject to exogenous financial disturbance $\epsilon_{t}^{f d}$, uniformly endured by all entrepreneurs and follows $\epsilon_{t}^{f d}=\rho_{\epsilon} f d * \epsilon_{t-1}^{f d}+\varepsilon_{t}^{f d}$ where $\varepsilon_{t}^{f d} \sim i . i . d . N\left(0, \sigma_{\varepsilon^{f d}}^{2}\right)$ and $\rho_{\epsilon} f d$ as coefficient of auto-covariance in exogenous AR(1) process.

Expected rate of return on capital depicted in equation 4 and expected cost of financing external funds, which can extracted from equation 5 determine the optimal demand for capital. Being risk neutral, entrepreneurs discount future more heavily than households and have finite expected horizon to rule out the possibility

\footnotetext{
${ }^{14}$ Higher the value of entrepreneurial balance sheet, higher the entrepreneurs stake in project, lower the moral hazard problem. Moreover, in case of financial sufficiency of entrepreneurs, agency problem does not materialize, risk free rate and rate of return on capital coincide and model collapses to state-of-art DSGE model by Smets and Wouters (2003).
} 
of self-financing their capital expenditure completely. The survival probability of entrepreneurs is given by $\theta$. Aggregate net worth accumulates according to following process.

$n w_{t}=\frac{k}{n w}\left(r_{t}^{k}-r_{t-1, t}^{k}\right)+r_{t-1, t}^{k}+\theta n w_{t-1}+\epsilon_{t}^{n w}$

$\epsilon_{t}^{n w}=\rho_{\epsilon^{n w}} * \epsilon_{t-1}^{n w}+\varepsilon_{t}^{n w} \quad$ where $\quad \varepsilon_{t}^{n w} \sim$ i.i.d.N $\left(0, \sigma_{\varepsilon^{n w}}^{2}\right) \quad$ and $\quad \rho_{\epsilon^{n w}} \quad$ as coefficient of auto-covariance in exogenous AR(1) process.

The aggregate net worth of entrepreneurs at the end of period is composed of equity held by entrepreneurs surviving from last period. $\frac{\mathrm{K}}{\mathrm{nw}}$ is the steady state capital expenditures as a ratio to entrepreneurial net worth, $r_{t}^{k}$ is actual rate of return on capital in current period while $r_{t-1, t}^{k}$ is rate of return on capital in last period. Equation 9 suggests that evolution of net worth is determined by difference between realized and expected rate of return on capital. The non- surviving entrepreneurs are supposed to consume their net worth

$$
c_{t}^{e}=(1-\theta) * n w_{t}
$$

Entrepreneurs are monopolistically competitive, produce intermediate goods, which are converted into homogeneous final goods by perfectly competitive final goods producers. Aggregate supply $y_{t}$ yields from a typical Cobb-Douglas technology augmented with fixed cost $\phi_{p}$, variable capital utilization rate and technology $\epsilon_{t}^{a}$ shock which is faced uniformly by all entrepreneurs.

$$
y_{t}=\phi_{p}\left(\alpha k_{t}^{s}+(1-\alpha) n_{t}+\epsilon_{t}^{a}\right)
$$

$\epsilon_{t}^{a}=\rho_{\epsilon^{a}} * \epsilon_{t-1}^{a}+\varepsilon_{t}^{a}$ where $\varepsilon_{t}^{a} \sim$ i.i.d.N $\left(0, \sigma_{\varepsilon^{a}}^{2}\right)$ and $\rho_{\epsilon^{a}}$ as coefficient of autocovariance in exogenous $\mathrm{AR}(1)$ process.

Where $\alpha$ shows the capital share in production. Capital service $k_{t}^{S}$ is the aggregation of existing capital stock and capital utilization rate $z_{t}$ and is given in equation below.

$$
k_{t}^{S}=k_{t-1}+z_{t}
$$

Moreover, equating the cost of higher utilization of capital with the rental price of capital services results in optimal capital utilization rate.

$$
z_{t}=\frac{1-\psi}{\psi} m p k_{t}
$$


where $\psi$ is elasticity of utilization cost with respect to capital inputs and $m p k_{t}$ is marginal product of capital which under cost-minimization problem takes the following form

$$
m p k_{t}=-\left(k_{t}^{s}-n_{t}\right)+w_{t}
$$

Marginal product of labor that also results from firm's cost minimization problem is given below

$$
m p n_{t}=\alpha\left(k_{t}^{s}-n_{t}\right)+\epsilon_{t}^{a}
$$

Similar to wages, price setting by monopolistically competitive firms also takes the form of staggered contracts. A fraction of firms finds the opportunity to revise prices with constant Calvo probability $\left(1-\xi_{p}\right)$ and sets prices a mark-up $\mu_{t}^{p}$ over wages. Those prices which are not re-optimized are indexed $\iota_{p}$ to past inflation partially. Consequently, inflation $\pi_{t}$ dynamics assume the following process.

$$
\pi_{t}=\frac{\beta}{1+\beta \iota_{p}} \pi_{t+1}+\frac{\iota_{p}}{1+\beta \iota_{p}} \pi_{t-1}+\frac{1}{1+\beta \iota_{p}} \frac{1-\beta \xi_{p}\left(1-\xi_{p}\right)}{\xi_{p}\left(\phi_{p}-1\right) \varepsilon_{p}+1} \mu_{t}^{p}+\epsilon_{t}^{p}
$$

Equation (16) in a hybrid NK price Philips curve, where forward-looking behaviour is depicted by expected future inflation term $\pi_{t+1}$ and backward-looking part succeeds from partial indexation. A price mark-up shock $\epsilon_{t}^{p}$ also determines the evolution of current inflation process and is given as

$\epsilon_{t}^{p}=\rho_{\epsilon} p * \epsilon_{t-1}^{p}+\varepsilon_{t}^{p}$ where $\varepsilon_{t}^{p} \sim$ i.i.d. $N\left(0, \sigma_{\varepsilon}^{2}\right)$ and $\rho_{\epsilon} p$ is coefficient of autocovariance in exogenous $\operatorname{AR}(1)$ process defining the shock.

The resource constraint decomposes aggregate output in consumption, investment good, government expenditure and resource lost owing to variable capital utilization. The resource constraint is given in the following manner

$$
y_{t}=c_{y} c_{t}+c_{y}^{e} c_{t}^{e}+i_{y} i_{t}+z_{y} z_{t}+\epsilon_{t}^{g}
$$

Where $c_{y}, c_{y}^{e}, i_{y}$ and $z_{y}$ are steady state household consumption, entrepreneurial consumption, investment and capital utilization loss as a percentage of GDP, respectively. $\epsilon_{t}^{g}$ is government expenditure shock specified as $\epsilon_{t}^{g}=\rho_{\epsilon} g *$ $\epsilon_{t-1}^{g}+\varepsilon_{t}^{g}$ where $\varepsilon_{t}^{g} \sim i . i . d . N\left(0, \sigma_{\varepsilon}^{2}\right)$ and $\rho_{\epsilon} g$ is coefficient of auto-covariance in exogenous $\mathrm{AR}(1)$ process defining the shock. 


\subsection{The Policy Regimes}

Pertaining to the objectives of the study, the behaviour of model economy is compared under three policy regimes. The baseline regime follows the essence of Jackson Hole consensus where monetary policy assumes standard Taylor rule with interest smoothing. Symbolically,

$$
r_{t}=\rho_{r} r_{t-1}+\left(1-\rho_{r}\right) \rho_{\pi} \pi_{t}+\left(1-\rho_{r}\right) \rho_{y}\left(y_{t}-y_{t-1}\right)+\epsilon_{t}^{r}
$$

Where $\rho_{r}, \rho_{\pi}$ and $\rho_{y}$ are policy coefficients specified by central bank and $\epsilon_{t}^{r}$ is a monetary policy shock $\epsilon_{t}^{r}=\rho_{\epsilon} r * \epsilon_{t-1}^{r}+\varepsilon_{t}^{r}$ where $\varepsilon_{t}^{r} \sim i . i . d . N\left(0, \sigma_{\varepsilon^{r}}^{2}\right)$ and $\rho_{\epsilon^{r}}$ is coefficient of auto-covariance in exogenous $\operatorname{AR}(1)$ process defining the shock.

The second policy regime consists of augmented Taylor rule in which the policy interest rate reacts to current credit growth. In this case, the central bank uses the policy rate to regulate financial sector, i.e. central bank is allowed to lean against the wind. Contrary to prevalent literature, which augments Taylor rule with credit variables considering it as an important indicator of asset price busts and precursor to financial crises, we intend to examine how policy induces an environment for credit-driven growth (or fallouts otherwise) by stimulating (or impeding) the positive feedback from credit growth to macroeconomic growth. Our intuition is supported by the empirical literature mentioned in introduction that credit booms rarely induce financial imbalances in developing economies.

$r_{t}=\rho_{r} r_{t-1}+\left(1-\rho_{r}\right) \rho_{\pi} \pi_{t}+\left(1-\rho_{r}\right) \rho_{y}\left(y_{t}-y_{t-1}\right)+\left(1-\rho_{r}\right) \rho_{c g}\left(c g_{t}\right)+\epsilon_{t}^{r}$

Where $c g_{t}=\frac{b_{t}}{b_{t-1}}$ is credit growth, $\rho_{c g}$ captures the extent with which central bank responds to credit growth.

Third regime combines a macro-prudential rule with a standard Taylor rule assuming macro-prudential authority as primary overseer of financial sector with central bank pursuing inflation targeting only. Following Kannan et al. (2012) and Bailliu et al. (2015) macro-prudential tool is incorporated as a component of EFP and gets feedback from contemporaneous credit growth. The macro-prudential policy is also subject to an exogenous shock. This regime is consistent with aftercrises consensus on the respective role of monetary and macro-prudential policies.

$$
\begin{aligned}
& s_{t}=-\chi\left(n_{t}-q_{t}-k_{t}\right)+\epsilon_{t}^{f d}+\tau_{t} \\
& \tau_{t}=\rho_{\tau}\left(c g_{t}\right)+\epsilon_{t}^{\tau}
\end{aligned}
$$

Where $\tau_{t}>0$ and $\rho_{\tau}$ is feedback coefficient chosen by policy maker who may be central bank or not. The macro-prudential policy shock is entailed in $\epsilon_{t}^{\tau}$. 
$\epsilon_{t}^{\tau}=\rho_{\epsilon^{\tau}} * \epsilon_{t-1}^{\tau}+\varepsilon_{t}^{\tau}$ where $\varepsilon_{t}^{\tau} \sim i . i . d . N\left(0, \sigma_{\varepsilon^{\tau}}^{2}\right)$ and $\rho_{\epsilon^{\tau}}$ is coefficient of autocovariance in exogenous AR(1) process defining the shock.

Specifying three different policy regimes for Pakistan economy is not a mere methodological exercise, rather evidentially supported. In 2009, the State Bank of Pakistan (SBP) switched from monetary aggregates as nominal anchor to interest rate. Since then, despite fiscal dominance, underdeveloped financial market and diluted autonomy, the SBP formulates monetary policy under inflation targeting regime. Given growth is inflationary and inflation is volatile, the SBP also keeps growth objective high on its priority list. This policy framework conforms to first policy regime of our model economy.

Ensuring stability and efficiency of financial system have always been central to monetary policy operations in Pakistan for the broader realization of price and output stability goals. The on-going process of aligning regulatory framework with international standards proposed by Basel III accord evidently stipulates that nominal anchor accommodates financial stance in Pakistan. This evidence provides support for assuming second policy regime in our model economy. Along with the SBP, the Securities and Exchange Commission of Pakistan (SECP) works as a regulatory institution for financial markets particularly focusing on capital market and corporate sector of Pakistan. The third policy regime assumed in above exercise delineates a regulatory framework where regulatory authority (or authorities) has two tools at their disposal for macroeconomic adjustment, a nominal anchor and macro-prudential tool. This shared nature of regulatory jurisdiction exercised in Pakistan is concomitant with the third policy regime.

With the evidence of the conduct of monetary policy concomitant with all three types of policy regimes, it becomes imperative to ascertain their relative efficacy and bearing for macroeconomy.

\section{Data and Estimation}

We estimated the model with Bayesian technique using five observables for Pakistan. This section contains information regarding data and its transformation, values of calibrated parameters and prior and posterior distribution of estimated structural parameters.

\subsection{Data and Transformation}

The data covers the time period from 1972 Q-I to 2017 Q-IV for five observables; output, inflation, interest rate, investment and credit growth. For output and investment, data has been taken from Hanif et al. (2013) till 2013 and 
extrapolated for the remaining quarters. The data on the rest of variables have been taken from International Finance Statistics. As the model is in log linearized form, all the variables are expressed as percentage deviation from deterministic steady state. In order to make the observables consistent with variables in model, data is transformed following Pfeifer (2018). Specifically, at first step all the variables are deseasonalized and transformed into log form. As output and investment are trending variables, they are detrended by using one-sided HP filter. The resultant variables depict the deviation from long term trend and have 0 mean. Credit to private sector is also transformed in similar manner. Inflation and interest rate are stationary variables and have direct stationary equivalent in data. To match these variables with log-linearized variables in model percentage deviation of gross inflation and gross interest rate from a respective time-varying steady state/trend has been taken where quarterly gross interest rate has been obtained from the $4^{\text {th }}$ order geometric mean of annualized net interest rate. Symbolically,

$$
\begin{aligned}
& \pi_{t}=\log \left(\pi_{t}^{\text {data }}\right)-\log \left(\pi_{\text {trend }, t}^{\text {data }}\right) \\
& r_{t}=\log \left(1+\frac{r_{t}^{\text {data }}}{4 \times 100}\right)-\log \left(1+\frac{r_{t r e n d, t}^{\text {data }}}{4 \times 100}\right)
\end{aligned}
$$

\subsection{Priors Distribution}

Using the above observed variables Bayesian estimation technique is used to estimate some parameters of the model. The priors of structural parameters are reported in column 3-5 of Table 1 with estimated posterior statistics presented in column 6-9. Table 2 contains the prior and posterior distribution of persistence coefficient and shock parameters in the similar manner. We use DSGE literature to establish priors for our study, hence prior distribution is standard. We refer to Smets and Wouters (2003), Gilchrist et al. (2009) and Kamber et al. (2015) for determining the prior distribution of almost all parameters considered for estimation.

The parameters governing the utility function are assumed to follow following distributions. The mean value of habit persistence following a beta distribution is set at 0.7 with 0.1 standard error. The value is considered consistent to avoid consumption and equity premium puzzles in DSGE models. The intertemporal elasticity of substitution is assumed to fluctuate around 1.5 with a standard error of 0.375 and the elasticity of labor supply is set at 2 with a standard error of 0.75 , both following normal distributions.

The parameters determining the wage and inflation setting are assumed to follow beta distribution. The probabilities of Calvo staggered contracts are set to 
be around 0.5 for both prices and wages, indicating that price and wage contracts lasts on average for half a year. The prior mean of the degree of indexation to past inflation is also set at 0.5 in both goods and labor markets.

For production and investment, relevant parameters to be estimated are one plus fixed cost of production and curvature of investment adjustment cost. The prior on the adjustment cost parameter for investment and fixed cost in the production are set around 4 with a standard error of 1.5 and 1.45 with the spread fixed at 0.25 , respectively where both tend to follow normal distribution.

The parameters for Taylor rule and an augmented Taylor rule are: the longrun feedback on inflation and the output growth are defined by a Gamma distribution with mean 1.5 and 0.50 and standard errors 0.25 and 0.10 , respectively. The lagged interest rate which shows the persistence of the policy rule is assumed beta distributed around a mean of 0.70 with a standard error of 0.1 . The prior on the long run reaction coefficient to the credit growth in augmented Taylor rule is set to follow normal distribution with mean and standard error similar to one assumed for output growth. The feedback coefficient on credit growth in macroprudential regime follows gamma distribution fluctuating around 0.5 with standard error of 0.1 .

Along with above mentioned set of parameters, we also estimate the elasticity of the external finance premium with respect to leverage. In the case where this variable takes a value of zero, in absence of financial shock, financial conditions are not passed on to the real economy. By estimating this parameter, the degree of financial market frictions is determined which is necessary to explain the cyclical behavior of the Pakistan economy over the 1972-2016 period. Following the literature, we set prior for elasticity of EFP to a beta distribution with mean 0.07 with standard error of 0.02 .

The prior distribution for persistence and stochastic process are coherent as much as possible. Inverse gamma distribution with a mean of 0.10 and two degrees of freedom is assumed for all innovations. The persistence of all AR(1) processes is assumed to follow beta distribution with mean 0.6 and standard deviation 0.2. 
Table 1. Prior and Posterior Distribution of Structural Parameters

\begin{tabular}{|c|c|c|c|c|c|c|c|c|c|}
\hline \multirow{3}{*}{$\begin{array}{c}\text { Parameters } \\
h\end{array}$} & \multirow[b]{2}{*}{ Description } & \multicolumn{3}{|c|}{ Prior Distribution } & \multicolumn{5}{|c|}{ Posterior Distribution } \\
\hline & & Dist. & Mean & St. Dev & Mode & St.Dev & Mean & 10 percent & 90 percent \\
\hline & Habit Persistence & Beta & 0.70 & 0.10 & 0.79 & 0.005 & 0.80 & 0.78 & 0.80 \\
\hline $\boldsymbol{\theta}_{c}$ & Intertemporal Elasticity of Substitution & Normal & 1.5 & 0.375 & 1.65 & 0.34 & 1.69 & 1.16 & 2.22 \\
\hline$\theta_{n}$ & Frisch Elasticity of labor supply & Normal & 2.0 & 0.75 & 1.79 & 0.76 & 1.98 & 0.76 & 3.11 \\
\hline$\iota_{w}$ & Wage Indexation & Beta & 0.5 & 0.15 & 0.49 & 0.18 & 0.49 & 0.26 & 0.74 \\
\hline$\xi_{w}$ & Degree of Wage Stickiness & Beta & 0.5 & 0.10 & 0.45 & 0.05 & 0.44 & 0.37 & 0.52 \\
\hline$\phi_{p}$ & share of fixed cost in production & Normal & 1.45 & 0.25 & 1.57 & 0.23 & 1.57 & 1.23 & 1.92 \\
\hline$t_{p}$ & Price Indexation & Beta & 0.5 & 0.15 & 0.63 & 0.09 & 0.64 & 0.52 & 0.77 \\
\hline$\xi_{p}$ & Degree of Price Stickiness & Beta & 0.5 & 0.10 & 0.73 & 0.03 & 0.73 & 0.69 & 0.77 \\
\hline$\varphi$ & Curvature of Investment Adjustment Cost & Normal & 4 & 1.5 & 1.83 & 1.38 & 2.2 & 0.23 & 3.92 \\
\hline$\chi$ & Elasticity of EFP w.r.t leverage & Beta & 0.25 & 0.05 & 0.07 & 0.014 & 0.08 & 0.05 & 0.10 \\
\hline$\tilde{\rho}_{r}$ & Interest Rate Smoothing & Beta & 0.70 & 0.10 & 0.97 & 0.01 & 0.97 & 0.96 & 0.98 \\
\hline$\rho_{\pi}$ & Response to inflation & Gamma & 1.5 & 0.25 & 0.92 & 0.06 & 0.87 & 0.76 & 0.97 \\
\hline$\rho_{y}$ & Response to output & Gamma & 0.5 & 0.10 & 0.44 & 0.08 & 0.43 & 0.29 & 0.57 \\
\hline$\rho_{c g}$ & Response to credit growth & Normal & 0.5 & 0.10 & 0.45 & 0.09 & 0.45 & 0.29 & 0.60 \\
\hline \multicolumn{10}{|c|}{ Table 2. Prior and Posterior Distribution of Shock Processes } \\
\hline$\gamma_{b}$ & Preference Shock & Beta & 0.6 & 0.2 & 0.72 & 0.22 & 0.62 & 0.31 & 0.91 \\
\hline$\gamma_{a}$ & Productivity Shock & Beta & 0.6 & 0.2 & 0.97 & 0.004 & 0.97 & 0.96 & 0.98 \\
\hline$\gamma_{q}$ & Price of Capital Shock & Beta & 0.6 & 0.2 & 0.17 & 0.10 & 0.18 & 0.04 & 0.32 \\
\hline$\gamma_{i}$ & Investment Efficiency Shock & Beta & 0.6 & 0.2 & 0.05 & 0.04 & 0.09 & 0.01 & 0.16 \\
\hline$\gamma_{w}$ & Wage Mark-up Shock & Beta & 0.6 & 0.2 & 0.6 & 0.28 & 0.57 & 0.28 & 0.98 \\
\hline$\gamma_{p}$ & Price Mark-up Shock & Beta & 0.6 & 0.2 & 0.97 & 0.001 & 0.973 & 0.972 & 0.976 \\
\hline$\gamma_{g}$ & Fiscal Policy Shock & Beta & 0.6 & 0.2 & 0.99 & 0.001 & 0.99 & 0.985 & 0.989 \\
\hline$\gamma_{r}$ & Interest Rate Shock & Beta & 0.6 & 0.2 & 0.10 & 0.06 & 0.12 & 0.03 & 0.23 \\
\hline$\gamma_{n w}$ & Net Worth Shock & Beta & 0.6 & 0.2 & 0.18 & 0.09 & 0.18 & 0.04 & 0.31 \\
\hline$\sigma_{b}$ & Preference Shock & Inv. Gamma & 0.10 & 2 & 0.13 & 0.04 & 0.14 & 0.08 & 0.20 \\
\hline$\sigma_{a}$ & Productivity Shock & Inv. Gamma & 0.10 & 2 & 0.03 & 0.01 & 0.03 & 0.02 & 0.04 \\
\hline$\sigma_{q}$ & Price of Capital Shock & Inv. Gamma & 0.10 & 2 & 0.02 & 0.002 & 0.02 & 0.01 & 0.03 \\
\hline$\sigma_{i}$ & Investment Efficiency Shock & Inv. Gamma & 0.10 & 2 & 0.12 & 0.01 & 0.12 & 0.10 & 0.14 \\
\hline$\sigma_{w}$ & Wage Mark-up Shock & Inv. Gamma & 0.10 & 2 & 0.04 & 0.01 & 0.07 & 0.02 & 0.11 \\
\hline$\sigma_{p}$ & Price Mark-up Shock & Inv. Gamma & 0.10 & 2 & 0.01 & 0.001 & 0.01 & 0.008 & 0.011 \\
\hline$\sigma_{g}$ & Fiscal Policy Shock & Inv. Gamma & 0.10 & 2 & 0.07 & 0.004 & 0.07 & 0.06 & 0.08 \\
\hline$\sigma_{r}$ & Interest Rate Shock & Inv. Gamma & 0.10 & 2 & 0.007 & 0.0004 & 0.007 & 0.006 & 0.008 \\
\hline$\sigma_{n w}$ & Net Worth Shock & Inv. Gamma & 0.10 & 2 & 0.04 & 0.01 & 0.04 & 0.02 & 0.07 \\
\hline$\sigma_{f}$ & Financial Shock & Inv. Gamma & 0.6 & 0.2 & 0.02 & 0.004 & 0.03 & 0.02 & 0.031 \\
\hline \multicolumn{10}{|c|}{ Note: The prior distribution is obtained from 3 chains of Metropolis Hasting algorithm } \\
\hline
\end{tabular}




\subsection{Calibrated Parameters}

The rest of parameters are treated fixed priors as data on selected observables does not contain sufficient information for all the parameters. In our earlier paper, we made use of several sources to calibrate parameters for Pakistan economy. Hence, we inherit the values of fixed priors from Tufail and Ahmed (2018) and report them in table 3 . The value of $\beta$ is set at 0.998 which is calculated as a reciprocal of steady-state quarterly gross interest rate. Compatible with existing literature on developing countries generally and Pakistan particularly (Ahmed et al., 2012), capital-output share is fixed at 0.49. Consistent with annual depreciation rate of 0.10 , the average quarterly depreciation rate, $\delta$ of 0.025 is calibrated. Elasticity of substitution between differentiated labor, $\varepsilon_{\mathrm{w}}$ and different varieties of intermediate good, $\varepsilon_{\mathrm{p}}$ is set at 6 which ensures a wage and price mark-up of 20 percent -a value frequently used in DSGE literature. The survival rate for entrepreneur, $\theta$ is set to 0.99 percent which implies an entrepreneur lives on average for more than 24 quarters or 6 years.

Table 3: Parameters Calibration

\begin{tabular}{|c|c|c|c|c|}
\hline Parameter & Description & Value & Estimation & Data/Reference \\
\hline$\beta$ & Discount factor & 0.998 & Data & Quarterly Data/IMF \\
\hline $\boldsymbol{\delta}$ & Depreciation Rate & 0.025 & Data & $\begin{array}{l}\text { Annual Data /SBP and } \\
\text { Penn World Table. } \\
\text { Parameters adjusted for } \\
\text { quarterly response }\end{array}$ \\
\hline$\varepsilon_{\mathrm{w}}$ & $\begin{array}{l}\text { Curvature of Dixit- } \\
\text { Stigler Aggregator }\end{array}$ & 6 & Literature & $\begin{array}{l}\text { Choudhri and Malik } \\
\text { (2012); }\end{array}$ \\
\hline$\alpha$ & $\begin{array}{l}\text { Share of Capital in } \\
\text { Production }\end{array}$ & 0.49 & Cointegration & $\begin{array}{l}\text { Annual Data/ } \\
\text { Coefficients adjust for } \\
\text { quarterly response }\end{array}$ \\
\hline$\psi$ & $\begin{array}{l}\text { Elasticity of capital } \\
\text { utilization }\end{array}$ & 0.54 & Literature & \\
\hline$\phi_{\mathbf{p}}$ & $\begin{array}{l}\text { Proportion of sticky } \\
\text { prices }\end{array}$ & 0.08 & Literature & Ahmed et al. (2012) \\
\hline$\varepsilon_{\mathrm{p}}$ & $\begin{array}{l}\text { Curvature of Dixit- } \\
\text { Stigler Aggregator }\end{array}$ & 6 & Literature & $\begin{array}{l}\text { Choudhri and Malik } \\
\text { (2012); }\end{array}$ \\
\hline $\boldsymbol{\theta}$ & $\begin{array}{l}\text { Entrepreneurial } \\
\text { survival rate }\end{array}$ & 0.99 & Literature & Bernanke et al. (1999) \\
\hline \multicolumn{5}{|c|}{ Steady State Values in model Economy } \\
\hline $\mathbf{c}_{\mathbf{y}}$ & $\begin{array}{l}\text { Consumption to GDP } \\
\text { ratio }\end{array}$ & 0.80 & Data & $\begin{array}{l}\text { Handbook of Statistics } \\
\text { on Pakistan Economy }\end{array}$ \\
\hline
\end{tabular}




\begin{tabular}{|c|c|c|c|c|}
\hline $\mathbf{c}_{\mathbf{y}}^{\mathbf{e}}$ & $\begin{array}{l}\text { Entrepreneurial } \\
\text { consumption to GDP } \\
\text { ratio }\end{array}$ & 0.01 & Literature & \\
\hline $\mathbf{i}_{\mathbf{y}}$ & $\begin{array}{l}\text { Investment to GDP } \\
\text { ratio }\end{array}$ & 0.18 & Data & $\begin{array}{l}\text { Handbook of Statistics } \\
\text { on Pakistan Economy }\end{array}$ \\
\hline $\mathbf{z}_{\mathbf{y}}$ & $\begin{array}{l}\text { Proportion of output } \\
\text { lost due to capacity } \\
\text { utilization }\end{array}$ & 0.01 & Literature & \\
\hline $\mathbf{k} / \mathbf{n w}$ & $\begin{array}{l}\text { Steady state level of } \\
\text { capital to net worth } \\
\text { ratio }\end{array}$ & 1.24 & Data & $\begin{array}{l}\text { Firms' annual financial } \\
\text { accounts by SBP }\end{array}$ \\
\hline
\end{tabular}

Source: Tufail and Ahmad (2018)

\subsection{Posterior Distribution}

Posterior distribution of structural parameters is given table 1 . The posterior estimate for habit formation turned out to be 0.79 , which is statistically significant. Havranek et al. (2017) reported that mean value of habit formation obtained from 129 estimated DSGE models to be closer to 0.73 for the US, the EU, the OECD and the Japan. However, many studies have reported this estimate to lie between 0.8 0.9. For EDEs placed closer to left tail of income distribution, a higher value of habit stock is more plausible. For other structural parameters related to utility function, mean of the posterior distribution is comparatively close to the mean of the prior assumptions.

The estimated mean for inflation indexation in both goods and labor market reveal that degree of price indexation with previous inflation is higher as compared to wages whose posterior distribution is not different from its prior assumption. For stickiness, the results are contrary to widespread literature, which report relatively higher frequency of price change than wage change. However, this implication arises from research conducted for developed countries. For developing countries like Pakistan, the higher prevalence of market failure, and the inefficiency of nonmarket institution to ameliorate the consequences reduces the frequency of price change. Accordingly, greater extent of price rigidity abridges the span of wage rigidity. Our results show that an average wage contract withstands for duration of two quarters while average estimated duration of price contract is slightly less than a year.

The estimated value of the elasticity of the external finance premium with respect to firm leverage is 0.08 and statistically significant. The value is higher than calibrated and estimated value for developed countries, that is 0.05 (see for 
example, Bernanke et al., 1999; Bernanke and Gertler, 2001). Our estimated value is closer to Meier and Muller (2006) that found it to be 0.07 but found it to be statistically insignificant.

The adjustment cost parameter is estimated to be 2.2 which is quite higher than the value obtained in literature with financial frictions. With the higher capital adjustment costs, capital price is more impulsive to shocks and makes net worth more volatile. This is directly transmitted to the cost of external funding. On the other hand, higher adjustment cost also suggests investment to be expensive and less responsive to shocks.

The lagged policy coefficient in monetary policy rule reveals a very higher degree of interest rate smoothing (0.97). The sluggish nature of adjustment process by central bank partly explains the high rigidity of prices. The reaction coefficients on inflation and output gap are 0.92 and 0.44 respectively. Similarly, policy response to credit growth is estimated to be 0.45 , which shows that policy rate responds to output and credit growth by almost same degree. There is no general agreement in Pakistan for estimates of reaction coefficients in monetary policy rule. For instance, Malik and Ahmed (2010) argued that monetary policy in Pakistan is highly accommodative as weights on inflation (0.32) and output (0.19) in monetary policy rule diverge considerably from what have been proposed by Taylor. Nevertheless, Haider and Khan (2008) in context of DSGE model showed that estimated coefficients (1.17 and 0.72 ) are closer to what conjectured by Taylor rule. The estimated coefficients of present study may be considered as an average with slightly accommodative monetary policy towards inflationary pressures while pursuing growth objective steadfastly. In this regard, we do not differ much from many other EDEs where monetary policy pursuits demand stabilization rigorously as fiscal policy accentuates the demand instabilities rather than tempering them.

The estimated coefficients for persistence of shocks reveal that fiscal policy, productivity and price mark-up shocks are highly persistent followed by preference shock. This is highly consistent with existing literature and depicts that observables have appealing information about the exogenous AR(1) processes. The high persistence of these shocks implies that most of the forecast error variance of endogenous variables will be attributed to these shocks in long run. Both financial and interest rate shocks are less persistent and less volatile as measured by the low value of their standard deviation. The distributions for prior and posterior are posted in figure 6 in appendix B. 


\section{Results and Discussion}

\subsection{Impulse Response}

To ascertain the concerns discussed earlier, we analyze the propagation mechanism of different shocks under three policy regimes considered in our model economy. For brevity, we have only presented the impulse responses to policy, financial and productivity shocks in main text. The impulse response functions for the rest of the shocks are presented in appendix C figure 7-10.

\subsubsection{Monetary Shock}

Figure 1 plots the responses of major macroeconomic variable to unexpected monetary policy shock. Persistence of monetary tightening following a monetary shock may either be due to deliberate policy inertia where central bank enforces partial adjustment process on its instrument (Clarida et al., 2000) or may owe to the presence of serially correlated shocks not systematically modelled in parsimonious interest rate rule such as Taylor rule.

A very high posterior estimate of interest rate smoothing coefficient in our case depicts the past-dependent nature of monetary policy in Pakistan. The presence of price puzzle also results from the influence of interest rate smoothing on inflation expectation (Woodford, 2004). It is also consistent with the dominance of 'supply channel' over 'traditional demand channel' in the transmission mechanism of monetary policy shock, which is evident in decline in asset value and increase in EFP. ${ }^{15}$ Thus, the effect of a contractionary monetary policy shock on the economy works, in part, by enhancing the cost of external funds through worsening the strength of borrowers' balance sheets. Increase in EFP and corresponding reduction in net worth is more distinct in third policy regime, which is solely attributed to macro-prudential contraction.

A contractionary monetary policy shock induces output and investment to decline, and with peak response materializing at fourth quarter for output and third quarter for investment, respectively. These responses conform to conventional evidence regarding both the strength of the monetary transmission mechanism as well as the length of the average lag of the economy's response to monetary policy actions. This largely owes to some of the real rigidities in the economy particularly habit persistence and investment adjustment cost.

\footnotetext{
${ }^{15}$ Supply channel corresponds to cost channel where monetary policy influences inflation through marginal cost of firms while demand channel works through inter-temporal allocation decision of agents.
} 
Figure 1. Monetary Policy Shock

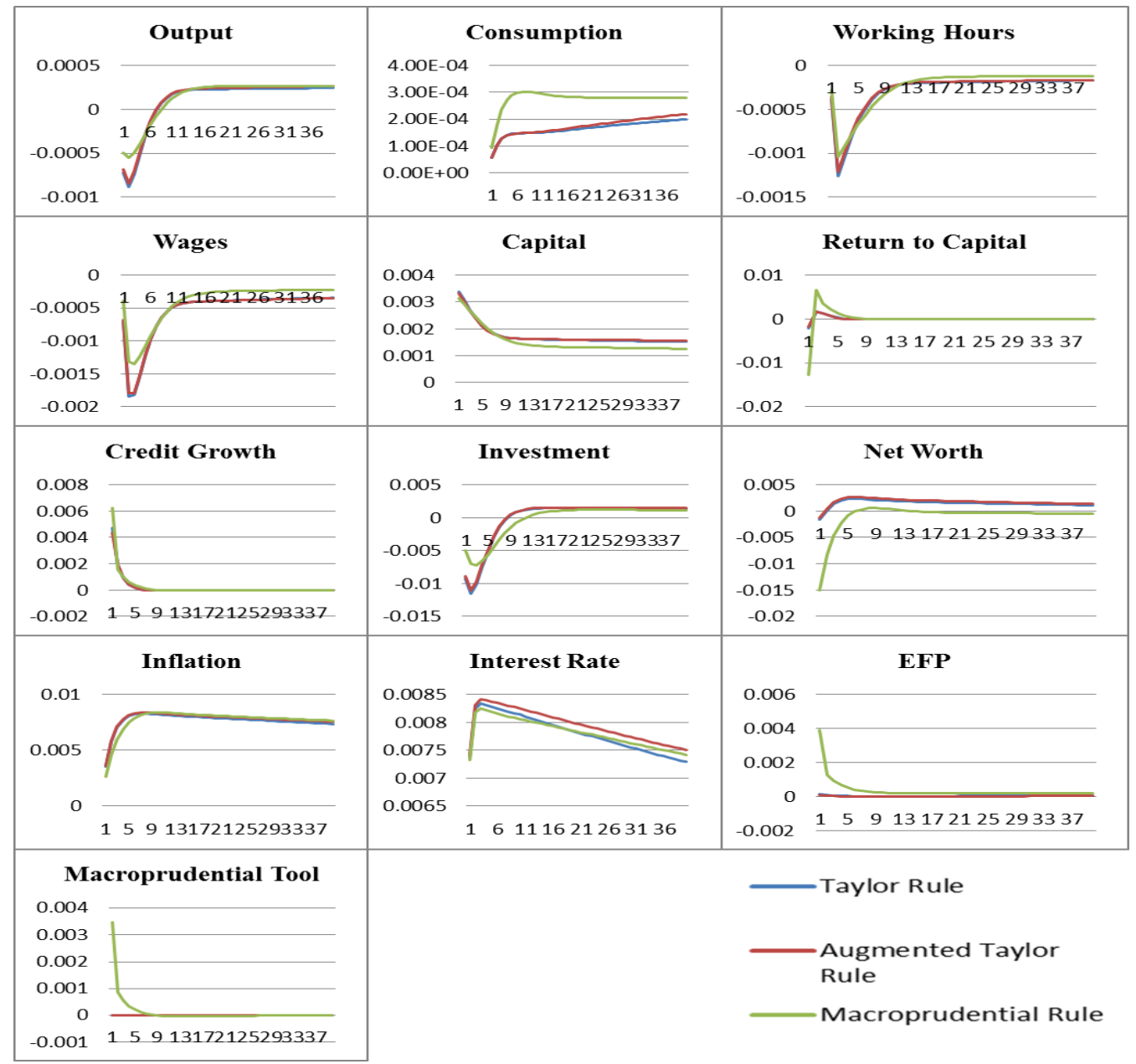

Source: Data Generated Output

Credit expansion ensuing a monetary contraction not only demonstrates the incidence of cost channel but also highlights certain rigidities faced by firms to change their short term nominal expenditures. Expansion in loans advanced, concurrent with both real and financial contraction, seems at first surprising. Nonetheless, it is indicative of two imperative insights; neither credit growth is moving along the business and financial cycle nor it is directed towards activities that could curtail the recessionary impact of adverse shocks. Historically, a bulk of loans advancements have been concentrated to a few conglomerates in Pakistan, which have limited role to play for macroeconomic momentum. More recently, 
these cash-rich conglomerates are becoming more reliant on their own resources to finance their investment expenditures. With this hindsight, the contrary response of investment and credit growth to adverse monetary shock seems highly reconcilable where former is pro-cyclical and later is incoherent with macroeconomic dynamics. International credit rating agencies also inferred that current credit profile of country is undermining the potential growth rather than stimulating it. Moreover, a surge in consumer finance innovation also concomitant with increase in consumption explains the increase in loans advancement, yet the results needed to be accepted with great caution as our model economy only features savers households.

Apart from negligible changes in magnitude, macroeconomic behaviour is consistent across all policy regimes implying that in face of monetary policy shock, monetary authority with simple Taylor rule is at par with two other policy regimes. Moreover, monetary 'only' regimes stabilize the financial impact of monetary tightening better as depicted in the trivial response of EFP and net worth to an adverse monetary policy shock.

\subsubsection{Fiscal Shock}

Opposite responses of credit growth and investment as depicted in figure 2, when an expansionary fiscal shock erupts, further authenticates credit independence nature of investment in Pakistan. Despite that fiscal expansions stimulate monetary contraction, investment and consumption multipliers remain intact. Increase in ex-ante interest rate is in line with Perotti (2005) and Bhattarai and Trzeciakiewicz (2017). Inflation reduces on impact but the evidence for the fiscal theory of price level is realized in later quarters. Across the policy regimes, the behaviour of consumption and EFP differs under third policy regime where monetary 'only' regimes are characterized with negligible change in EFP while under last one EFP reduces significantly owing to relatively moderate macroprudential regulation. However, the lax regulations could not persuade credit expansions, most probably due to higher appetite of credit by government (which is 40 percent of total credit in Pakistan) crowding out its availability for private sector. 


\section{Figure 2. Fiscal Policy Shock}

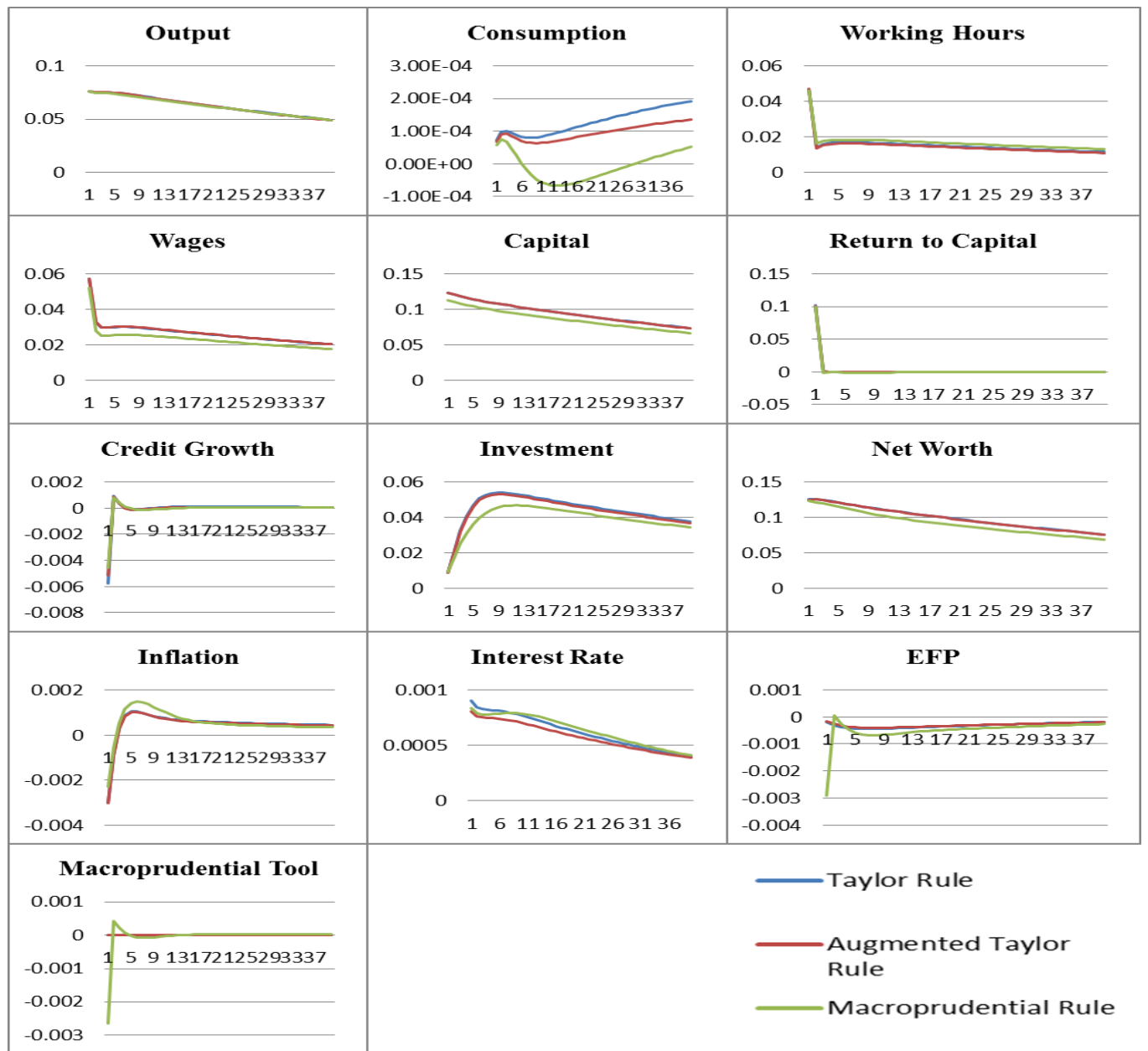

Source: Data Generated Output

\subsubsection{Financial Shocks}

A direct shock to EFP and indirect through unexpected macro-prudential policy shock channel to real variables analogously. Both type of financial shocks derive macroeconomic contractions, an increase in inflation and monetary tightening. A reduction in credit growth incites lax macro-prudential regulation in face of direct shock to EFP. The degree of real macroeconomic responses vary 
slightly across policy regimes, however, the divergence is reasonably clear in the responses of financial variables like net worth and credit growth.

The monetary 'only' policy regimes inhibit the declining trajectory of net worth and credit growth but divulge a higher concavity in output and investment reinforcing the earlier insights that financial growth and stability are not concomitant with macroeconomic growth and stability in Pakistan.

Other two financial shocks considered in our model economy and presented in figure 5 and 6 permeate to the economy through the firm's balance sheet either directly when encountered with unexpected shock in entrepreneurial net worth or indirectly with an exogenous increase in the price of capital.

\section{Figure 3. Exogenous Financial Shock}

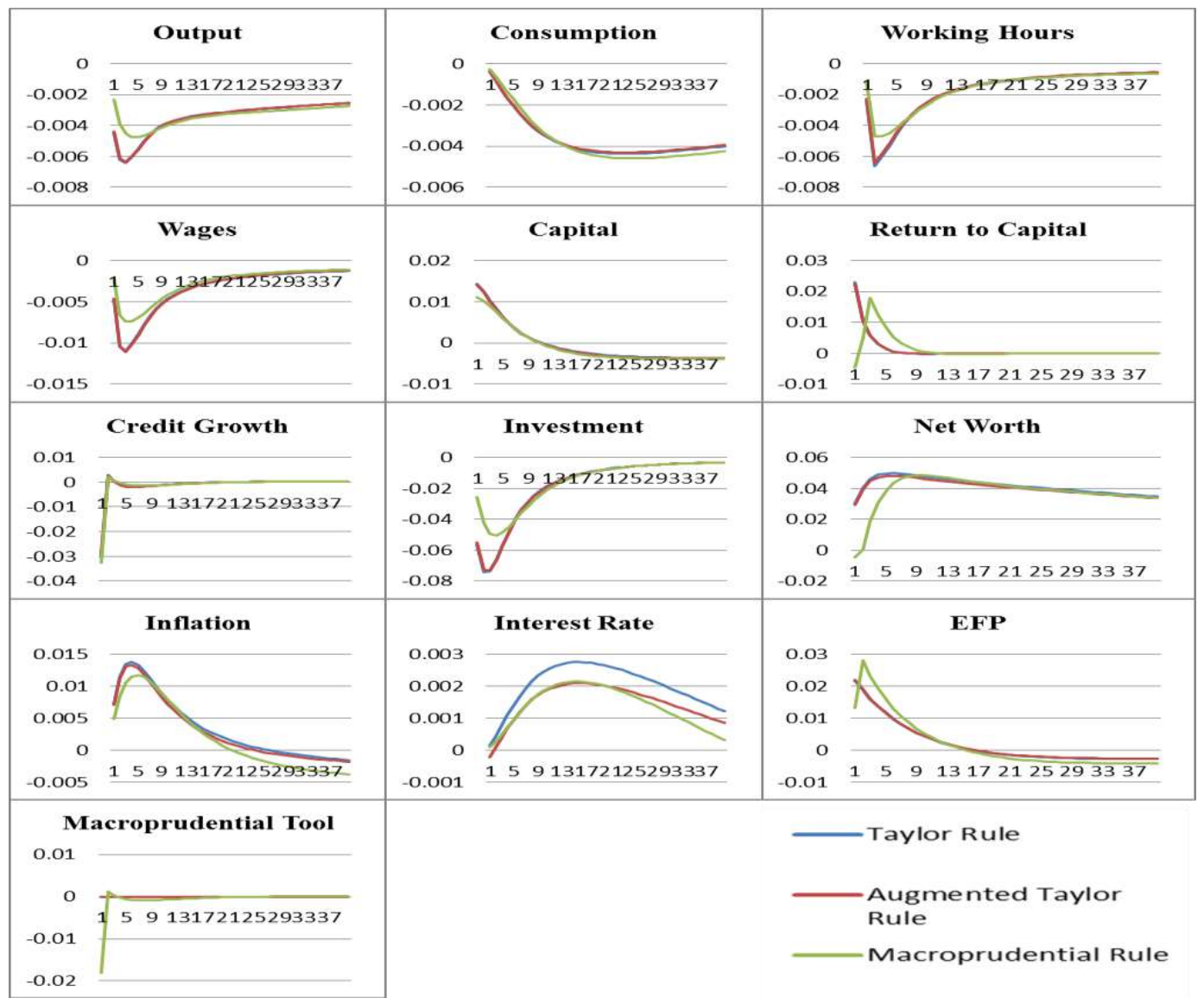

Source: Data Generated Output 
An adverse shock to entrepreneurial net worth is short lived and net worth converges to equilibrium in third quarter. For third policy regime, it also sustains for three quarters but is fostered above equilibrium before attenuating completely. Subsequently, varying macroeconomic dynamics materialize under different policy regimes. A reduction in net worth causes an increase in entrepreneurial leverage; hence, EFP escalates which is imperceptible for monetary 'only' regimes. Temporary deterioration in net worth keeps credit growth, output and investment below equilibrium for five, six and nine quarters respectively. Gilchrist et al. (2009) corroborated that a reduction in investment implies a decline in supply of capital and results in increase in marginal cost. Resultantly, net worth shock is inflationary which is also true for our model economy under first two regimes. It reduces consumption persistently under first policy regime; however, central bank's regulation of financial sector prevents the decrease in consumption.

The reaction of key macroeconomic variable to a net worth shock differs in several vital aspects for third policy regime. An on-impact increase in EFP and macro-prudential tool is tailed by a modest decline causing output and investment to boost up after preliminary weakening while a persistent increase in consumption. Net worth shock is deflationary when economy employs macro-prudential tools to regulate financial sector. Nonetheless, behaviour of credit growth is similar across all three regimes. The deterioration in net worth operates like a positive shock to demand of credit. With contraction in entrepreneurial wealth, the reliance on external funding increases causing a credit and EFP to follow the similar trajectory.

Shock to the price of capital transmits to the economy in multiple ways. Besides its direct bearing for real economy, it plays pivotal role in determining the borrower's credit worthiness and therefore, effects the investment and amounts of loan advanced to the economy. Real and financial effects of price of capital reinforce each other.

Figure 6 presents the response of key macroeconomic variables to one standard deviation positive shock to price of capital. A higher asset price manifested in higher value of Tobin's q, as described by Kamber et al. (2015) allows entrepreneur to increase both investment and consumption by lowering the cost of debt servicing. This is depicted in the responses of investment and consumption, which are of higher magnitude when macro-prudential regulations are turned off and monetary policy has only policy rate at its disposal to regulate the economy. The response of working hours and inflation also follow the same pattern. Financial impact of price of capital shock is amplified when interplay between macroprudential and monetary policies are allowed. As monetary policy accommodates 
financial sector in second regime, impact response of policy rate differ considerably in both regimes. However, under monetary 'only' regimes, both net worth and EFP respond slightly and favourable impact of price of capital on entrepreneur's net worth is mollified. In third regime, after the on impact decline in net worth, an increase in price of capital improves entrepreneurial net worth and hence reduces EFP. For all the policy regimes, credit growth shows exhibit similar dynamics.

\section{Figure 4. Macro-prudential Policy Shock}

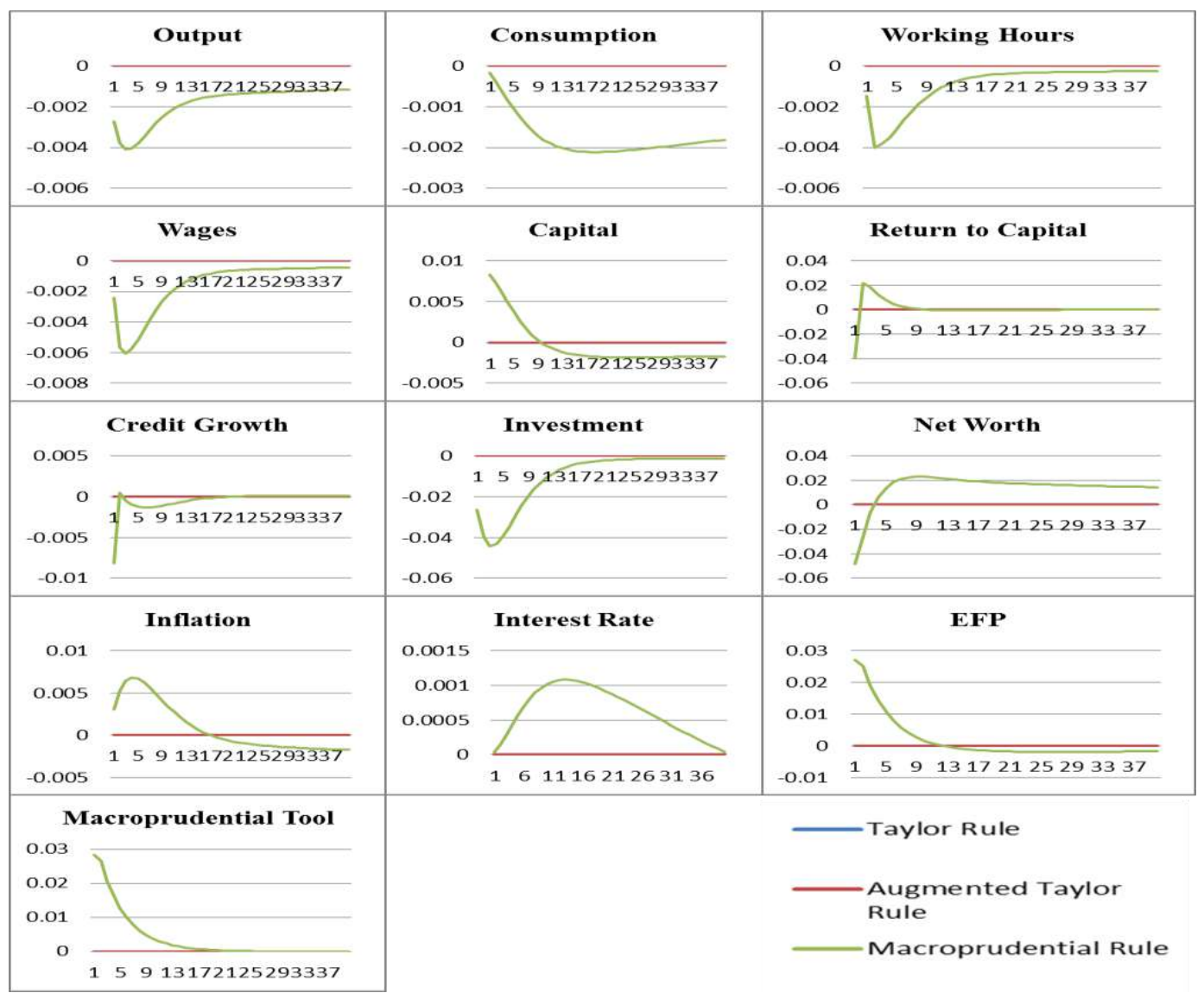

Source: Data Generated Output

The comparison of transmission mechanism of monetary and macroprudential policies is worth giving a glance. Peak contractions following a macroprudential policy shock materialize after 4 quarters, which is similar to the average lag monetary policy takes to pass on to the economy under both regimes. Though 
Finance-Growth Nexus and Relative Efficacy of Alternative Policy Regimes: An Investigation for Pakistan

the pattern output and investment assume following both the shocks is quite similar but the contraction is much profound in case of macro-prudential policy shock.

Figure 5. Net Worth Shock

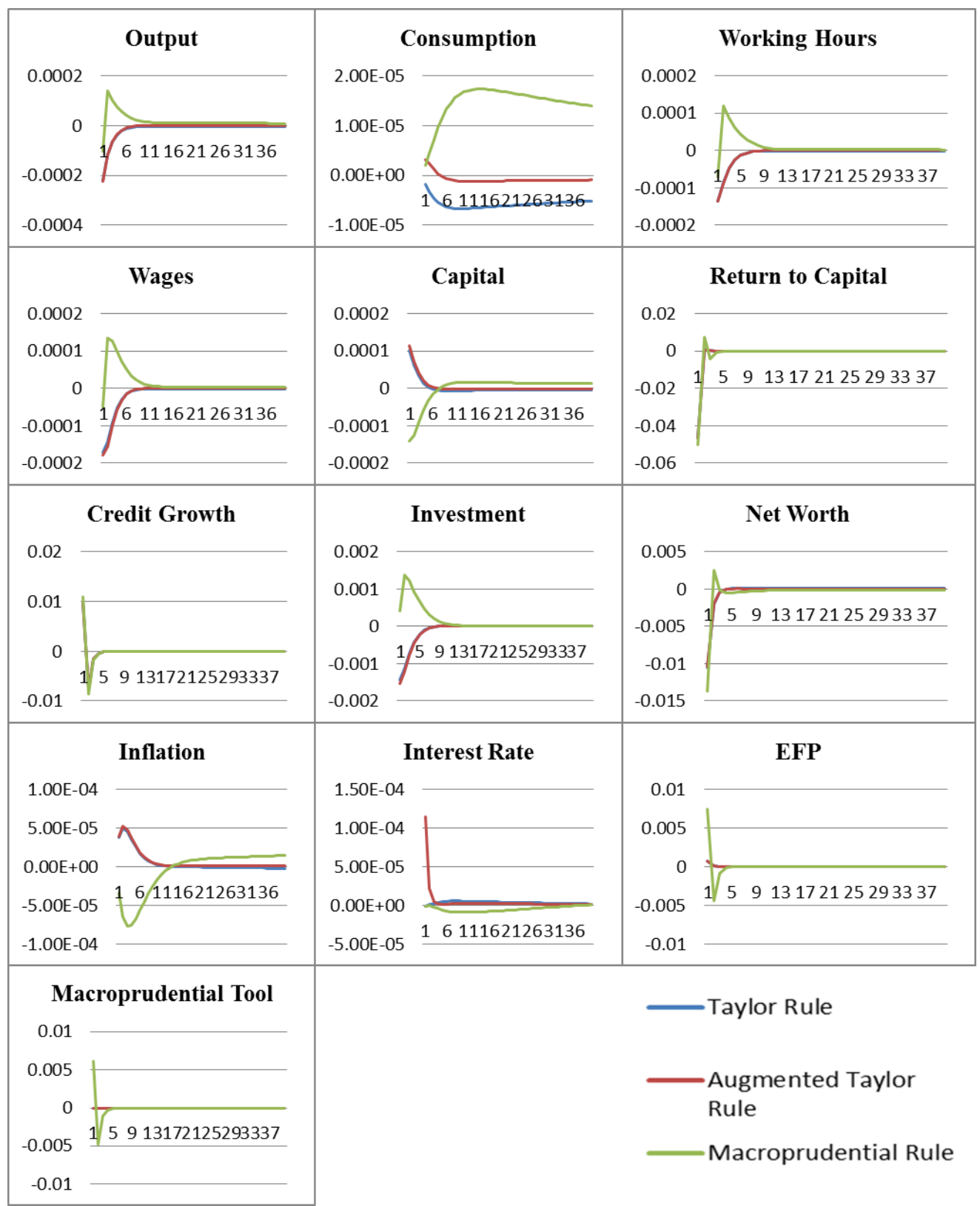

Source: Data Generated Output 
Figure 6. Price of Capital Shock

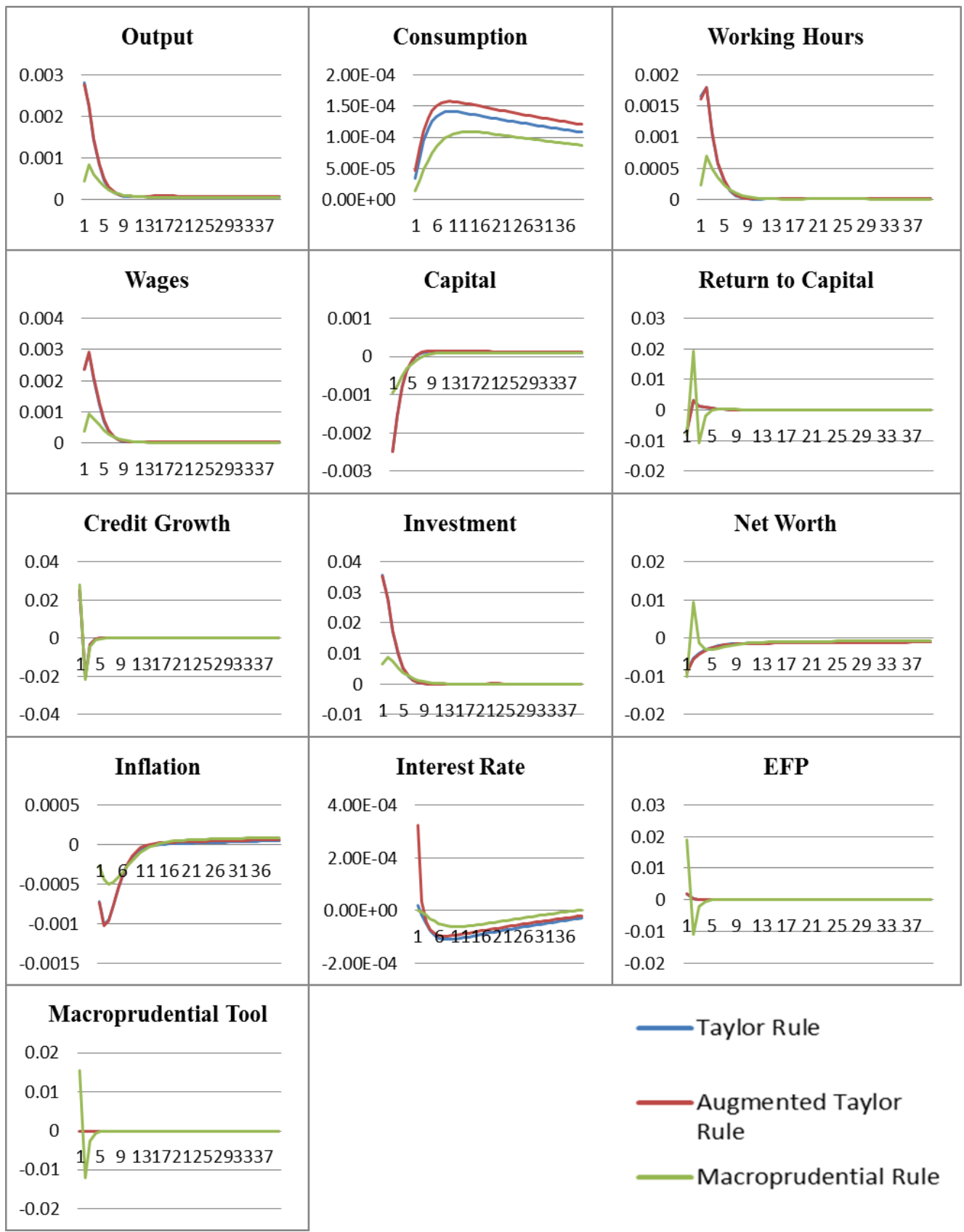

Source: Data Generated Output 
Monetary 'only' regimes also keep the financial aggregate stable and prevent the credit growth to fall despite prudent financial regulation -a scenario that is not retained in face of macro-prudential shock. Consumption being an important indicator of welfare also reduces persistently for macro-prudential shock, which is contrary to the dynamics confronted after monetary tightening.

\subsubsection{Productivity Shock}

Figure 7 presents the macroeconomic dynamics in our model economy to a positive productivity shock under three policy regimes considered. Generally, the responses of key macroeconomic variables are concomitant with existing literature. For output and investment, a humped shaped response is observed under all three regimes with the maximum gains procured under second regime. For consumption, regime difference is immaterial. Interest rate and inflation also decrease immediately after an on impact positive response. According to Bailliu et al. (2015) the extent of monetary easing is more under regime where central bank accounts for financial sector as central bank is expected to increase the policy rate when credit growth increases due to productivity shock.

In our model economy, on impact and over the horizon decline in interest rate is more in second regime but it does not intend to regulate for increase in credit growth by raising expected policy rate. Rather, it appears to control for debt deflation impact arising from decrease in inflation, which is also of higher degree under second regime. Debt deflation effect also results in lower net worth, high price of capital and dampened demand for capital (Christensen \& Dib, 2008). The adverse impact of decline in net worth is transmitted to EFP only in third regime whereas monetary 'only' regimes appear to control for financial sector instability by declining interest rate by higher amount. Consequently, credit growth remained unreceptive to productivity shock in monetary 'only' regimes while in third regime it declines on impact and converges to equilibrium in second quarter primarily owing to decline macro-prudential regulations. Like in sticky-price models, hours worked reduce in face of positive technology shock. The response of hours worked, however, is not substantially different in the models with different policy regimes.

Relevant to the objectives of our study, the results from impulse response function highlight that growth is not credit driven primarily due to worsening capital profile of Pakistan. Moreover, the results of study points towards the coherency between price and financial stability goals of central bank and adhere to Jackson Hole consensus given in first policy regime. Macro-prudential regulation is less effective in stabilizing financial sector then when central bank leaves it unattended or leans against the wind. Moreover, growth momentum associated with 
credit expansions is nowhere to be seen, it implies that macro-prudential regulations presents policy dilemma.

\section{Figure 7. Productivity Shock}

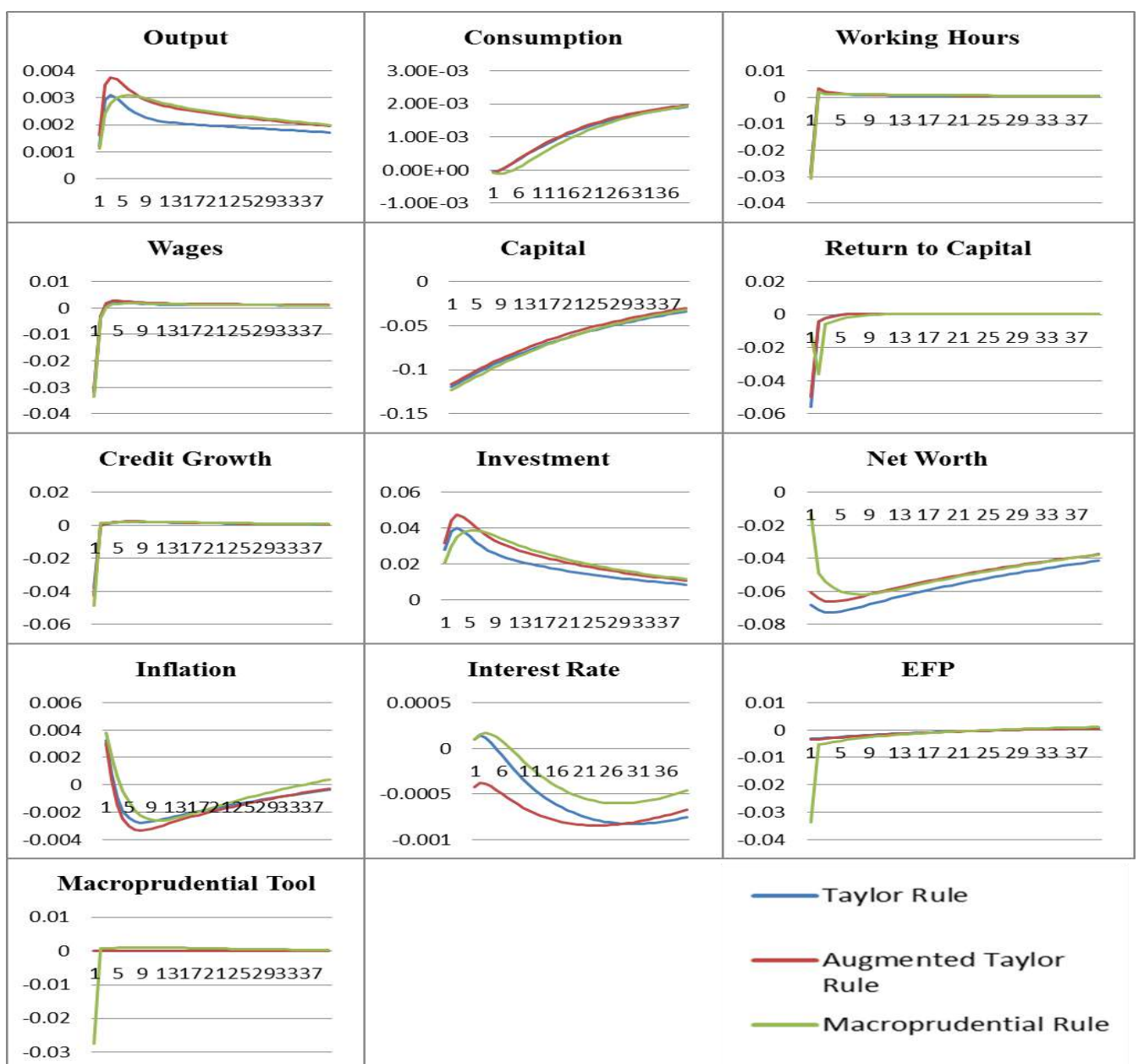

Source: Dynare generated output

\subsection{Historical Decomposition of Shocks}

To examine the historical relevance of different disturbances for macroeconomic performance over the period from 1972-2016 period, time-paths of different endogenous variables around their steady state inferred by each of the model shocks is plotted. For the purposes of elucidation, the financial shocks 
emanating from EFP (direct shock to EFP and macro-prudential policy shock) are merged and labelled as EFP shock. Similarly, financial shocks deriving net worth (direct shock to net worth and price of capital shock) are combined together and termed as net worth shock. Below we present the historical shock decomposition of variables most relevant for the objectives of the study.

Figure 8 depicts the historical decomposition of GDP growth. The solid line is the smoothed series obtained from Kalman Filter. Fiscal policy shocks remained the dominant source of economic fluctuation throughout the sample selected. Apart from fiscal shock, EFP shocks have been the main driver for the increase in growth whereas plunges are evidently accredited to productivity and price mark-up shock. The lessening contribution of financial shock for increasing economic growth is obvious after in the current decade, which is also consistent with the deteriorating credit profit of the country.

Inflation appears to be more persistent (presented in figure 9) than economic growth. Increase in inflation during different periods can be ascribed to monetary and financial shocks while decrease in inflation is a result of reduction in mark-up along with EFP. This is pointing towards the prevalence of conviction and inflation is monetary phenomenon.

Figure 8. Historical Decomposition of Output Growth

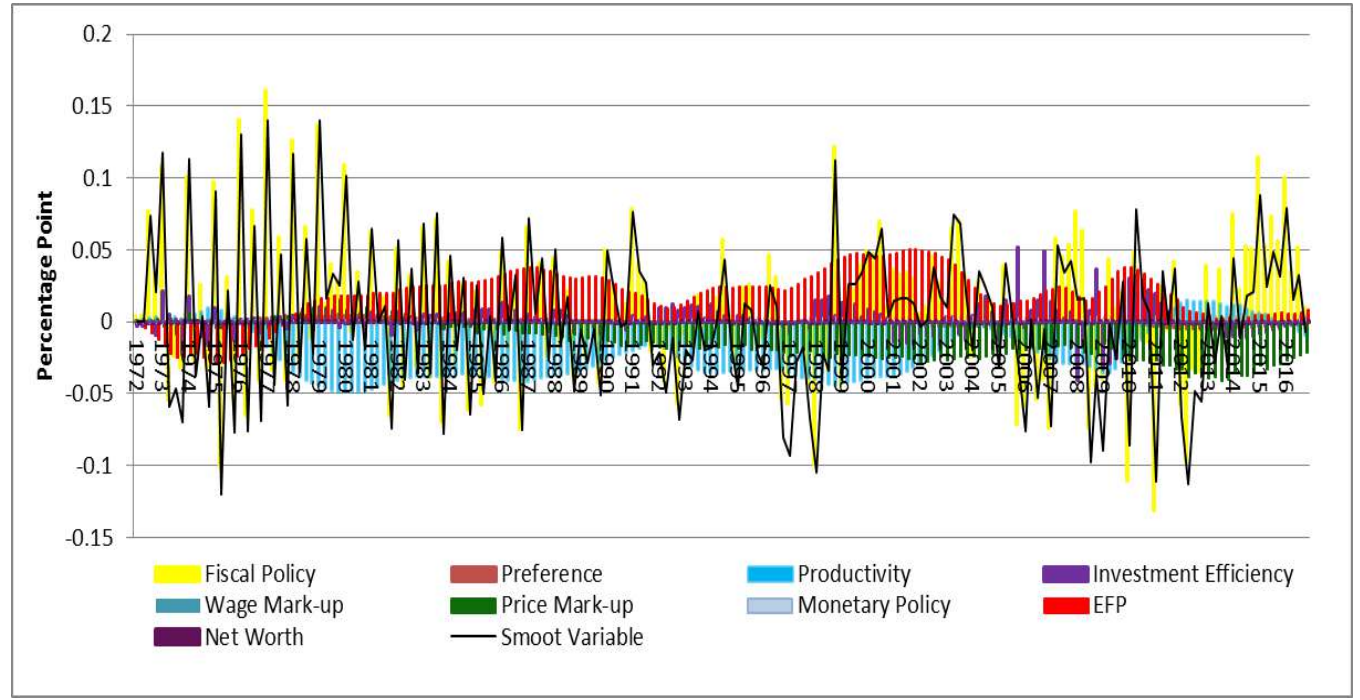


Figure 9. Historical Decomposition of Inflation

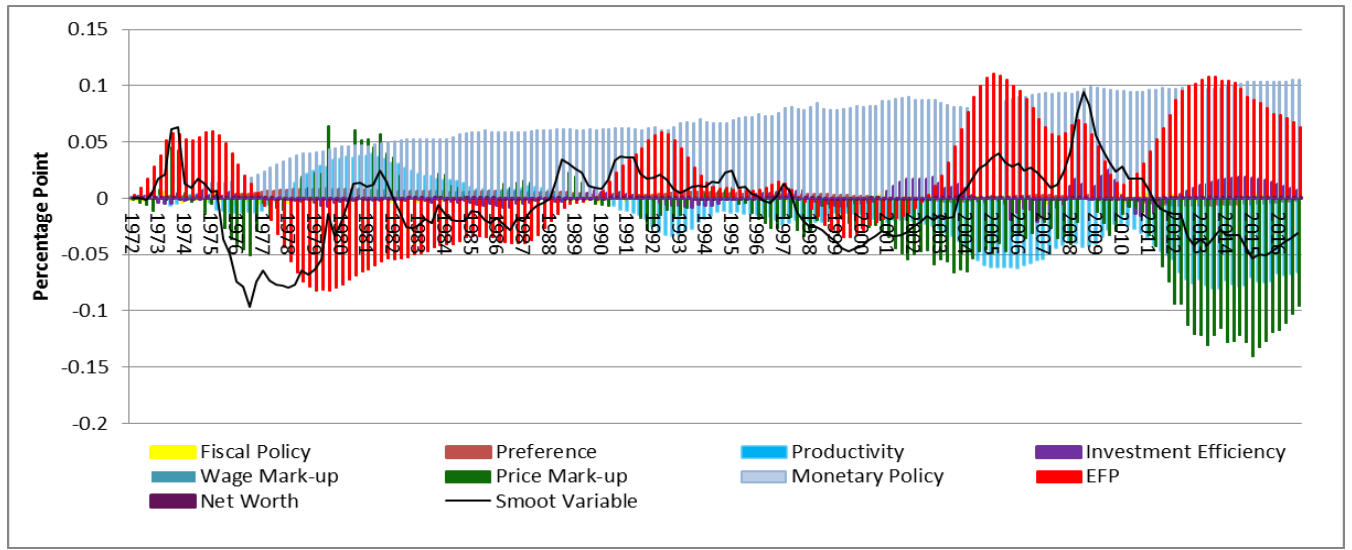

Figure 10. Historical Decomposition of Credit Growth

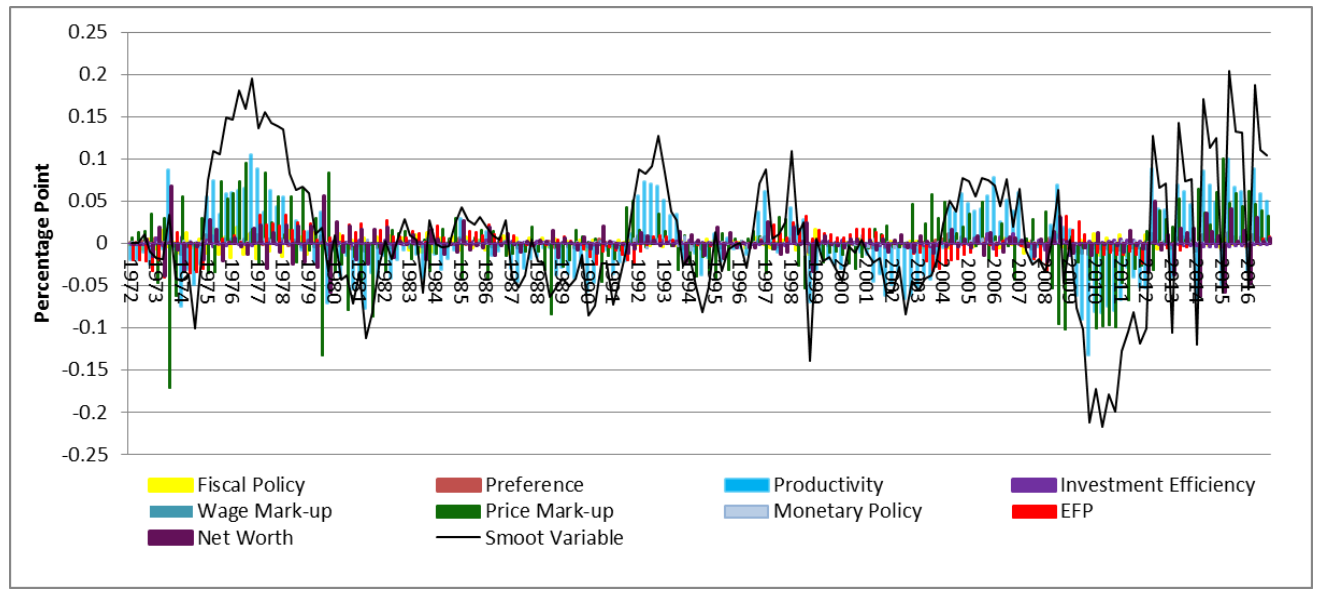


Figure 11. Historical Decomposition of Investment

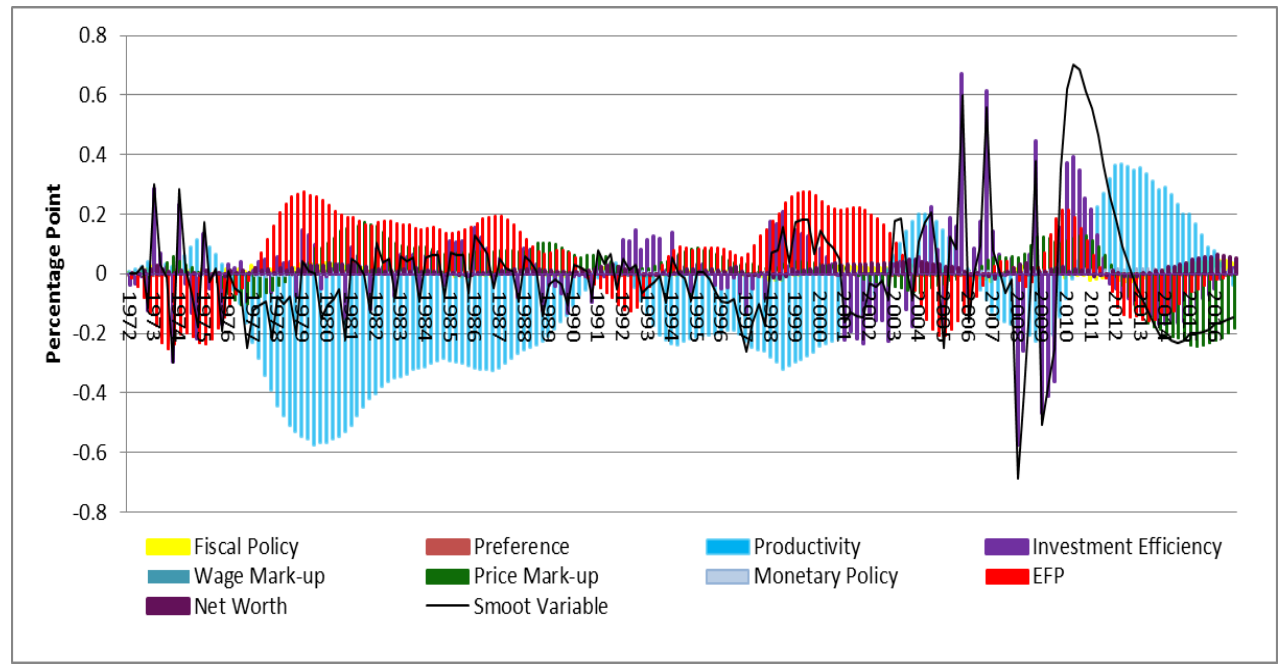

Source: Dynare generated output

The decomposition of credit growth presented in figure 10 largely explains the acyclical or counter-cyclical movement of credit growth in face of different shock observed in impulse response functions. Neither monetary nor macroprudential regulation have been pivotal for credit growth in Pakistan rather its deviations from steady state are mostly determined by price mark-up and productivity shocks faced by entrepreneurs. Similarly, contribution of negative productivity shocks is also ubiquitous in the reduction in investment throughout the sample period. Investment is persistently trailed by investment efficiency shocks.

\section{Conclusion and Recommendations}

In this study, we investigated the finance growth nexus to address the longstanding question in the operation of monetary policy along with some of recent concerns related to the role of macro-prudential regulations in business cycle. In context of New Keynesian DSGE model estimated for a financially underdeveloped country, Pakistan, the findings of the study showed that finance growth nexus does not exist in Pakistan and financial and economic cycles are segregated in face of different shocks. The study underscores several apprehensions that necessitate precedence in the formulation of both financial and monetary policies. 
Firstly, the findings of study showed the segregation of financial and business cycles, implying that financial variables are relatively less informative in predicting major macroeconomic aggregates in face of different shocks. It is in sharp contrast to widespread conviction that financial sector embeds expected macroeconomic behaviour as it is instantaneous recipient and absorber of information shocks. The segregation of financial and business activities suggests that financial sector is not the catalyst for various macroeconomic and even financial sector related shocks in Pakistan. It may either be due to higher resilience and efficiency of the system and/or inadequate outreach of the system to shape macroeconomic behaviour. The most trumpeted credit-growth nexus does not exist in Pakistan which may show that policy makers are concentrating on financial efficiency at the cost of financial depth and outreach. Our results are different from previous studies on this issue for Pakistan which found a positive relationship between credit and economic growth. This shows that the existence of direct causal relationship does not ensure the comovement of financial and economic variables over the business cycle. However, like our findings, Khan and Qayyum (2007) and Jalil and Feridun (2014) also recommended the acceleration of financial reform process to realize gains from finance-growth nexus.

This finding of the study has very important policy implication. Given the current financial profile of the country, financial stability concerns posed by GFC accredited to credit boom and bust cycle are not pertinent for Pakistan. Nonetheless, the SBP efforts to affix these concerns as depicted in austere commitment to Basel III and macro-prudential regulation seems to overshadow its endeavor for financial development. In this regard, it is suggested that the Bank may reconsider its choice in the trade-off between financial growth and stability. Given the imperceptible relationship between credit and economic growth, the efforts for financial development may not vent out crises associated with rapid credit expansion.

Secondly, historical shock decomposition analysis further entails that both financial and monetary policies have limited role to play in financial development as indicated by credit growth. It is, rather determined by productivity and price shocks directly faced by the entrepreneurs. This suggests that as long as entrepreneurs are not insured against certain shocks even easy access to finance will not boost financial development. The deterioration in credit profile of country, therefore, may be attributed to both uninsured uncertainties faced by entrepreneur and supply side constraints imposed by strict regulations. This is further reinforced in the pro-cyclicality of investment despite credit conditions, depicting increasing reliance on self and/or informal financing of investment expenditures. Though the SBP has taken many ventures for promotion of SMEs and easy financing, it is not 
enough to outperform the role of fiscal shock that delineates the trajectory of economic growth more than fifty percent. It asserts that improvement in the transmission of monetary policy calls for limiting the government role in private sector activities.

Thirdly, regarding the efficacy of monetary policy for financial management, the findings from study are somehow straightforward. Almost in face of every shock, the response of almost all the variables under monetary 'only' regimes is same. This postulates that policy regime characterized by Jackson Hole consensus is as efficient as the one that calls for leaning against the wind. By specifying monetary policy to a traditional Taylor rule with carefully chosen weights on inflation and output, the central bank can achieve financial stability through price stability. Hence, central bank goals of price and financial stability are coherent. However, if taken carefully results indicate rather a bigger dilemma -that reconciles with our earlier conjectures - that highly passive development of financial sector, its inability to shape and to keep pace with macroeconomic aggregates, does not necessitate further regulation. It is further depicted in the responses of key aggregates in third policy regime where the introduction of macroprudential policy as suggested by findings of the study is at best futile and at least recessionary for many shocks. Particularly, it does not outdo monetary 'only' regimes for stabilizing financial sector in face of different shocks. It implies monetary policy is not "too blunt" an instrument for countries like Pakistan contrary to recent consensus for developed countries.

Amongst the first few studies for EDEs on this issue, the study faces certain limitations one of which is related to the selection of estimated priors. The priors used for advanced economies are fairly standard, however, for EDEs there is need to explore the values and distributions of these priors. 


\section{References}

Ahmed, W., Haider, A., \& Iqbal, J. (2012). Estimation of discount factor (beta) and coefficient of relative risk aversion (gamma) in selected countries. MPRA Paper 39736, University Library of Munich, Germany.

Angelini, P., Nicoletti-Altimari, S., \& Visco, I. (2012). 22. Macroprudential, Microprudential and Monetary Policies: Conflicts, Complementarities and Trade-Offs. Stability of the Financial System: Illusion Or Feasible Concept?, 474.

Arena, M., Bouza, S., Dabla-Norris, M. E., Gerling, M. K., \& Njie, L. (2015). Credit Booms and Macroeconomic Dynamics: Stylized Facts and Lessons for Low-Income Countries. International Monetary Fund.

Bailliu, J., Meh, C., \& Zhang, Y. (2015). Macroprudential rules and monetary policy when financial frictions matter. Economic Modelling, 50, 148-161.

Barajas, M. A., Beck, T., Dabla-Norris, M. E., \& Yousefi, M. R. (2013). Too cold, too hot, or just right? Assessing financial sector development across the globe (No.13-81). International Monetary Fund.

Benes, J., \& Kumhof, M. M. (2011). Risky bank lending and optimal capital adequacy regulation (No. 11-130). International Monetary Fund.

Bernanke, B. S., \& Gertler, M. (2001). Should central banks respond to movements in asset prices?. American economic review, 91(2), 253-257.

Bernanke, B. S., Gertler, M., \& Gilchrist, S. (1999). The financial accelerator in a quantitative business cycle framework. Handbook of macroeconomics, 1 , 1341-1393.

Bhattarai, K., \& Trzeciakiewicz, D. (2017). Macroeconomic impacts of fiscal policy shocks in the UK: A DSGE analysis. Economic Modelling, 61, 321338.

Blanchard, O., Dell'Ariccia, G., \& Mauro, P. (2010). Rethinking macroeconomic policy. Journal of Money, Credit and Banking, 42, 199-215.

Boar, C., Gambacorta, L., Lombardo, G., \& Pereira da Silva, L. A. (2017). What are the effects of macroprudential policies on macroeconomic performance?. BIS Quarterly Review September.

Cerra, V., \& Saxena, S. C. (2008). Growth dynamics: the myth of economic recovery. American Economic Review, 98(1), 439-57. 
Cerutti, E., Claessens, S., \& Laeven, M. L. (2015). The use and effectiveness of macroprudential policies: new evidence (No. 15-61). International Monetary Fund.

Chinn, M. (2015). 1 Notes on The Chinn-Ito Financial Openness Index 2013 Update.

Chinn, M. D., \& Ito, H. (2010). The chinn-ito index. A de jure measure of financial openness. Online version http://web. pdx. edu/ ito/Chinn-Ito_website. htm, 243-76.

Christensen, I., \& Dib, A. (2008). The financial accelerator in an estimated New Keynesian model. Review of Economic Dynamics, 11(1), 155-178.

Christensen, I., Meh, C., \& Moran, K. (2011). Bank leverage regulation and macroeconomic dynamics. Cahier de recherche/Working Paper, 11, 40.

Claessens, S. (2014). An overview of macroprudential policy tools (No. 14-214). International Monetary Fund.

Claessens, S., Kose, M. A., \& Terrones, M. E. (2011, May). Financial cycles: what? how? when?. In International Seminar on Macroeconomics (Vol. 7, No. 1, pp. 303-344). Chicago, IL: University of Chicago Press.

Cúrdia, V., \& Woodford, M. (2009). Conventional and unconventional monetary policy. FRB of New York Staff Report, (404).

Curdia, V., \& Woodford, M. (2009). Credit frictions and optimal monetary policy (Working Paper 278). Bank for International Settlements.

Dell'Ariccia, G., Igan, D., \& Laeven, L. U. (2012). Credit booms and lending standards: Evidence from the subprime mortgage market. Journal of Money, Credit and Banking, 44(2-3), 367-384.

Galí, J., \& Gambetti, L. (2015). The effects of monetary policy on stock market bubbles: Some evidence. American Economic Journal: Macroeconomics, 7(1), 233-57.

Gilchrist, S., \& Leahy, J. V. (2002). Monetary policy and asset prices. Journal of monetary Economics, 49(1), 75-97.

Gilchrist, S., Yankov, V., \& Zakrajšek, E. (2009). Credit market shocks and economic fluctuations: Evidence from corporate bond and stock markets. Journal of monetary Economics, 56(4), 471-493. 
Greenspan, A. (2002). Speech on economic volatility at a symposium sponsored by the Federal Reserve Bank of Kansas City. Jackson Hole, Wyoming, August, 30.

Goldstein, M., \& Xie, D. (2009). The impact of the financial crisis on emerging Asia. Peterson Institute for International Economics Working Paper, (09$11)$.

Gourinchas, P. O., Valdes, R., \& Landerretche, O. (2001). Lending booms: Latin America and the world (No. w8249). National Bureau of Economic Research.

Haider, A., \& Khan, S. U. (2008). A small open economy DSGE model for Pakistan.

Hanif, N., Iqbal, J., \& Malik, J. (2013). Quarterisation of national income accounts of Pakistan.

Havranek, T., Rusnak, M., \& Sokolova, A. (2017). Habit formation in consumption: A meta-analysis. European Economic Review, 95, 142-167.

Jalil, A., \& Feridun, M. (2011). Impact of financial development on economic growth: empirical evidence from Pakistan. Journal of the Asia Pacific Economy, 16(1), 71-80.

Khan, M. A., \& Qayyum, A. (2007). Trade liberalisation, financial development and economic growth (No. 2007: 19). Pakistan Institute of Development Economics

Khan, A., Ahmed, M., \& Bibi, S. (2019). Financial development and economic growth nexus for Pakistan: a revisit using maximum entropy bootstrap approach. Empirical Economics, 57(4), 1157-1169.

Kamber, G., Smith, C., \& Thoenissen, C. (2015). Financial frictions and the role of investment-specific technology shocks in the business cycle. Economic Modelling, 51, 571-582.

Kannan, P., Rabanal, P., \& Scott, A. M. (2012). Monetary and macroprudential policy rules in a model with house price booms. The BE Journal of Macroeconomics, 12(1).

Lane, P. R., \& Milesi-Ferretti, G. M. (2007). Europe and global imbalances. Economic Policy, 22(51), 520-573. 
Levine, R. (2012). Finance, regulation and inclusive growth. Promoting inclusive growth: Challenges and policies, 55-75.

Malik, W. S., \& Ahmed, A. M. (2010). Taylor rule and the macroeconomic performance in Pakistan. The Pakistan Development Review, 37-56.

Meier, A., \& Müller, G. J. (2006). Fleshing out the monetary transmission mechanism: Output composition and the role of financial frictions. Journal of Money, Credit and Banking, 2099-2133.

Mendoza, E. G., \& Terrones, M. E. (2008). An anatomy of credit booms: evidence from macro aggregates and micro data (No. w14049). National Bureau of Economic Research.

Meng, C., \& Gonzalez, R. L. (2017). Credit Booms in Developing Countries: Are They Different from Those in Advanced and Emerging Market Countries?. Open Economies Review, 28(3), 547-579.

Mishkin, F. S. (2011). Monetary policy strategy: lessons from the crisis (No. w16755). National Bureau of Economic Research.

Park, C. Y., \& Mercado Jr, R. V. (2014). Determinants of financial stress in emerging market economies. Journal of Banking \& Finance, 45, 199-224.

Perotti, R. (2005). Estimating the effects of fiscal policy in OECD countries.

Pfeifer, J. (2018). A guide to specifying observation equations for the estimation of dsge models. Research series, 1-150.

Quint, D., \& Rabanal, P. (2014). Monetary and macroprudential policy in an estimated DSGE model of the euro area (No. 2014/5). Diskussionsbeiträge.

Reinhart, C. M., \& Rogoff, K. S. (2009). The aftermath of financial crises. American Economic Review, 99(2), 466-72.

Rubio, M., \& Carrasco-Gallego, J. A. (2014). Macroprudential and monetary policies: Implications for financial stability and welfare. Journal of Banking \& Finance, 49, 326-336.

Schularick, M., \& Taylor, A. M. (2009). Credit Booms Gone Bust: Monetary Policy, Leverage cycles and Financial Crisis, 1870-2008. CEPR.

Smets, F. (2014). Financial stability and monetary policy: How closely interlinked?. International Journal of Central Banking, 10(2), 263-300. 
Smets, F., \& Wouters, R. (2003). An estimated dynamic stochastic general equilibrium model of the euro area. Journal of the European economic association, 1(5), 1123-1175.

Svensson, L. E. (2010). Inflation targeting. In Handbook of monetary economics (Vol. 3, pp. 1237-1302). Elsevier.

Svensson, L. E. (2012). Comment on Michael Woodford,'Inflation targeting and financial stability'. Sveriges Riksbank Economic Review, 1, 33-39.

Tornell, A., \& Westermann, F. (2002). Boom-bust cycles in middle income countries: Facts and explanation. IMF Staff Papers, 49(1), 111-155.

Tufail, S., \& Ahmad, A. M. (2018) Financial frictions and optimal policy response to shocks. Conference Proceeding, $34^{\text {th }}$ AGM, PSDE. PIDE

Woodford, M. (2004). Inflation targeting and optimal monetary policy.

Woodford, M. (2012). Methods of policy accommodation at the interest-rate lower bound.

Appendix A

Figure 1. Macro-prudential Policy Index* (2000-2017)

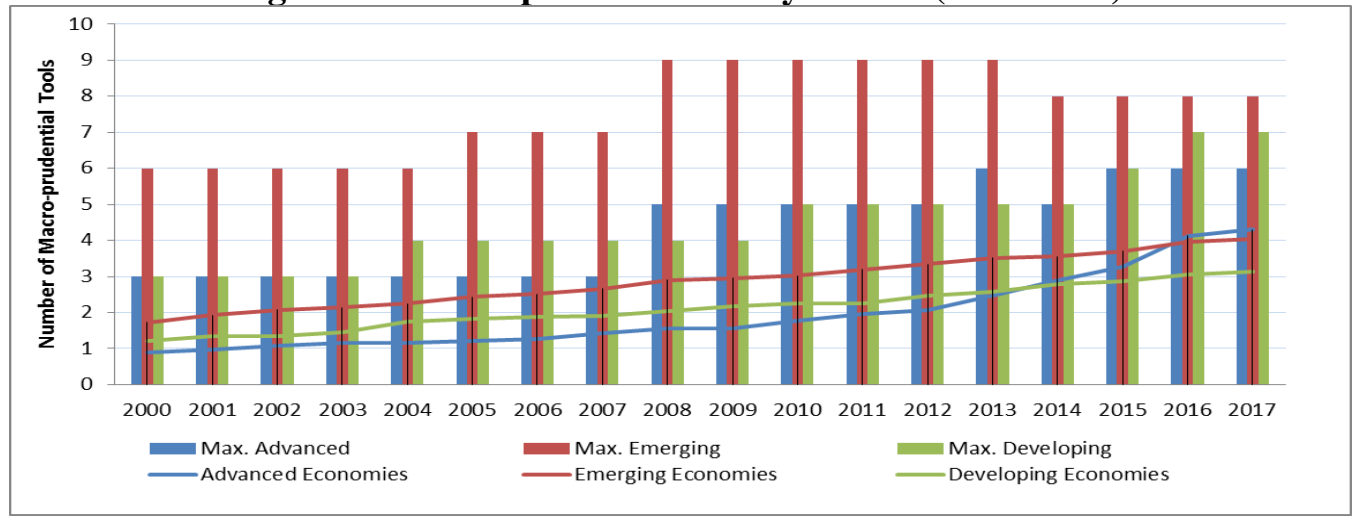

Source: 2018 update of Cerutti, Claessens, Laeven (2017) macroprudential policy dataset based on Global Macro-Prudential Policy Instruments (GMPI) survey by IMF.

*Note: Yearly averages are calculated by authors 
Figure 2. Financial Openness*

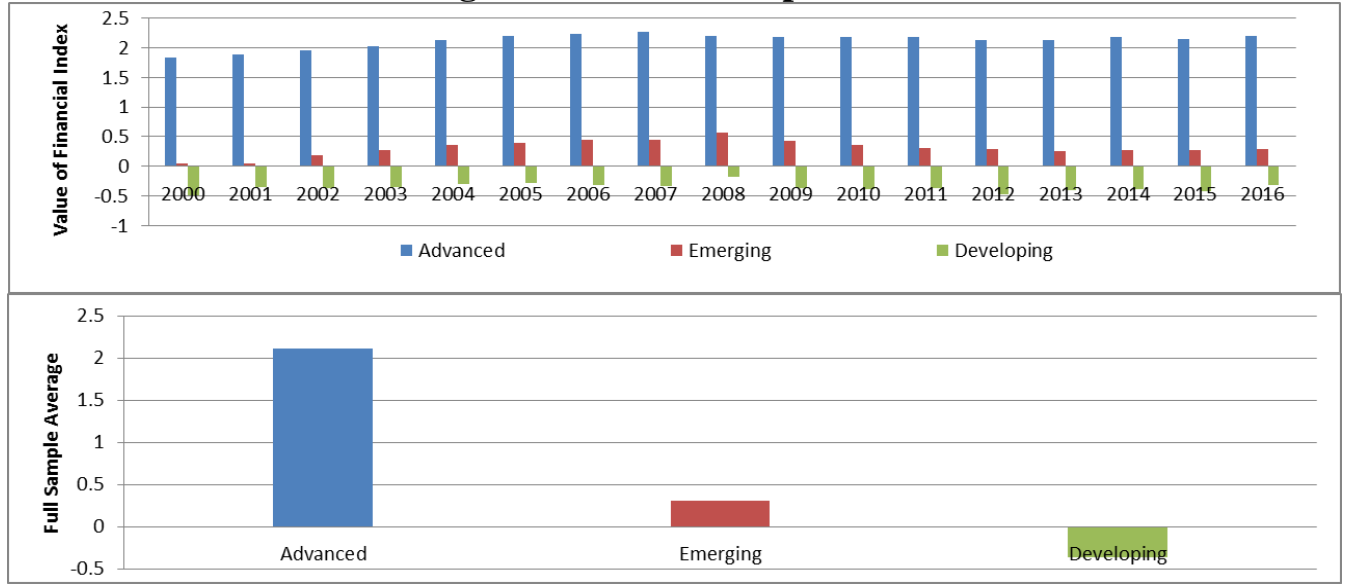

Source: Chinn-Ito Financial Openness Index

*Note: Yearly and full sample averages are calculated by authors

Figure 3. Financial Depth

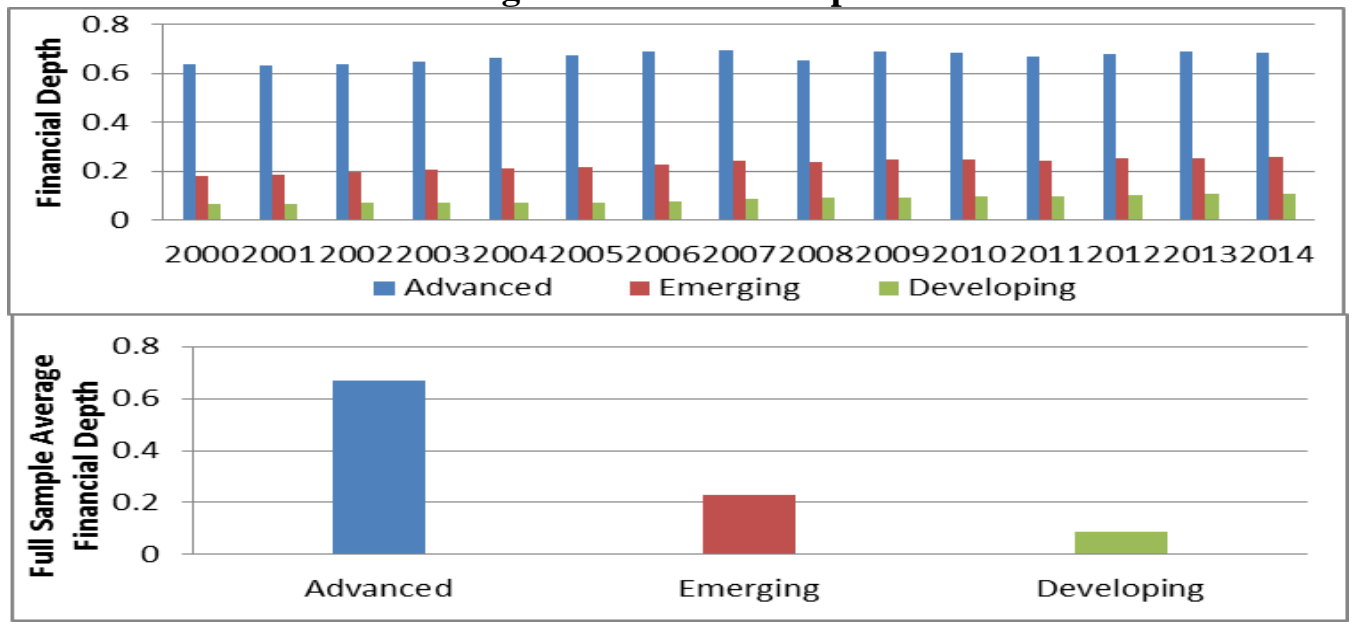

Source: Source: Global Financial Development Database by World Bank

*Note: Yearly and full sample averages are calculated by authors 
Figure 4. Financial Characteristics of Pakistan

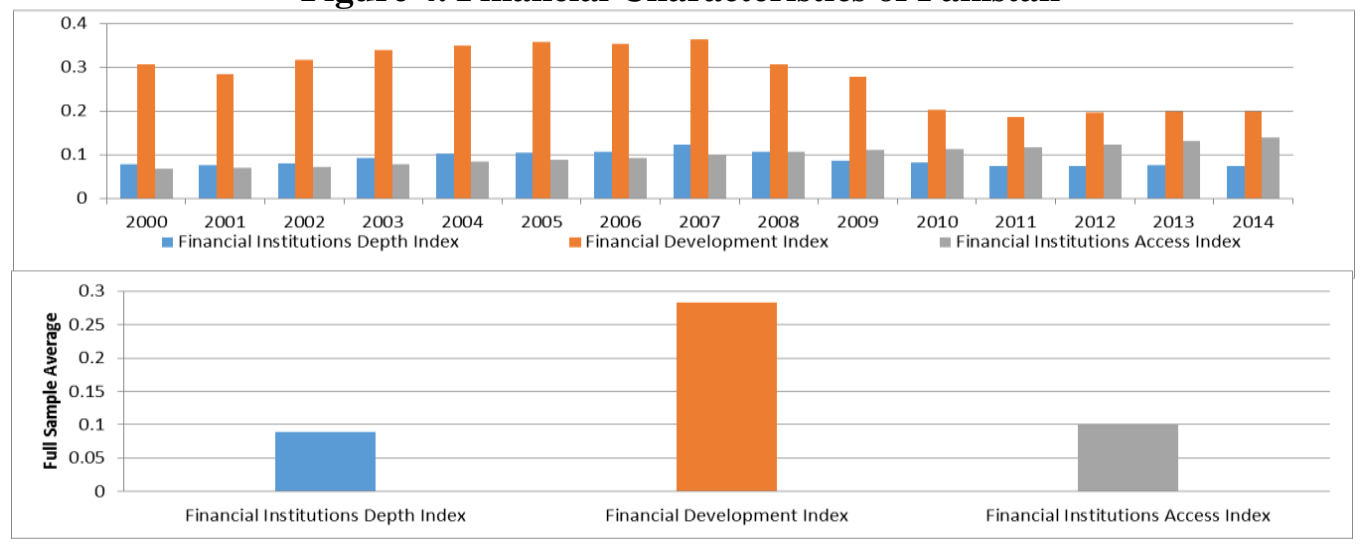

Source: Global Financial Development Database by World Bank

Figure 5. MPI: Pakistan versus Other Emerging and Developing Countries

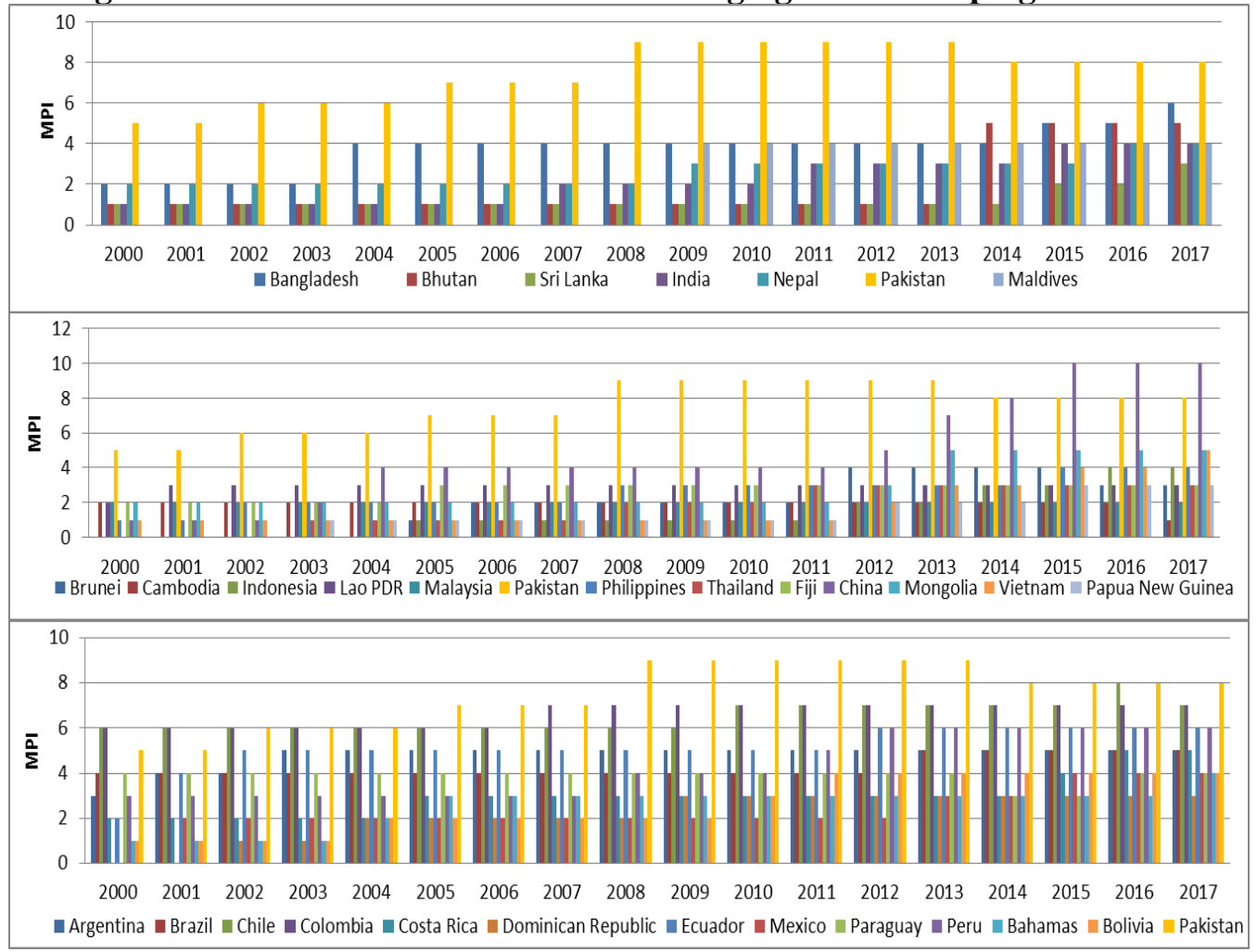

Source:2018 UPDATE of Cerutti, Claessens, and Laeven (2017) Macroprudential Dataset. 
Finance-Growth Nexus and Relative Efficacy of Alternative Policy Regimes: An Investigation for Pakistan

\section{Appendix B}

Figure 6: Prior and Posterior Distribution
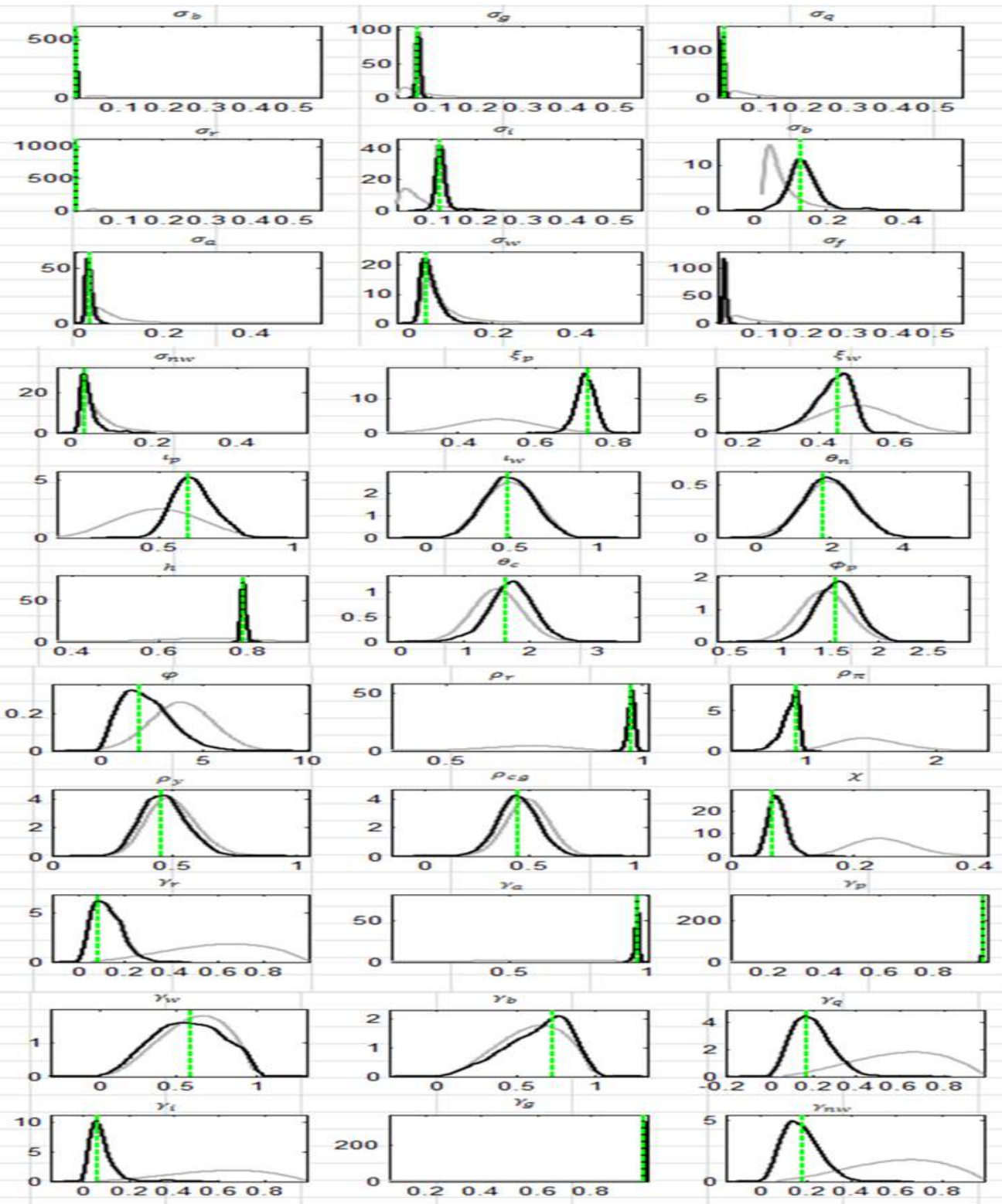

Source: Dynare Generated Output 


\section{Appendix C}

Figure 7. Preference Shock

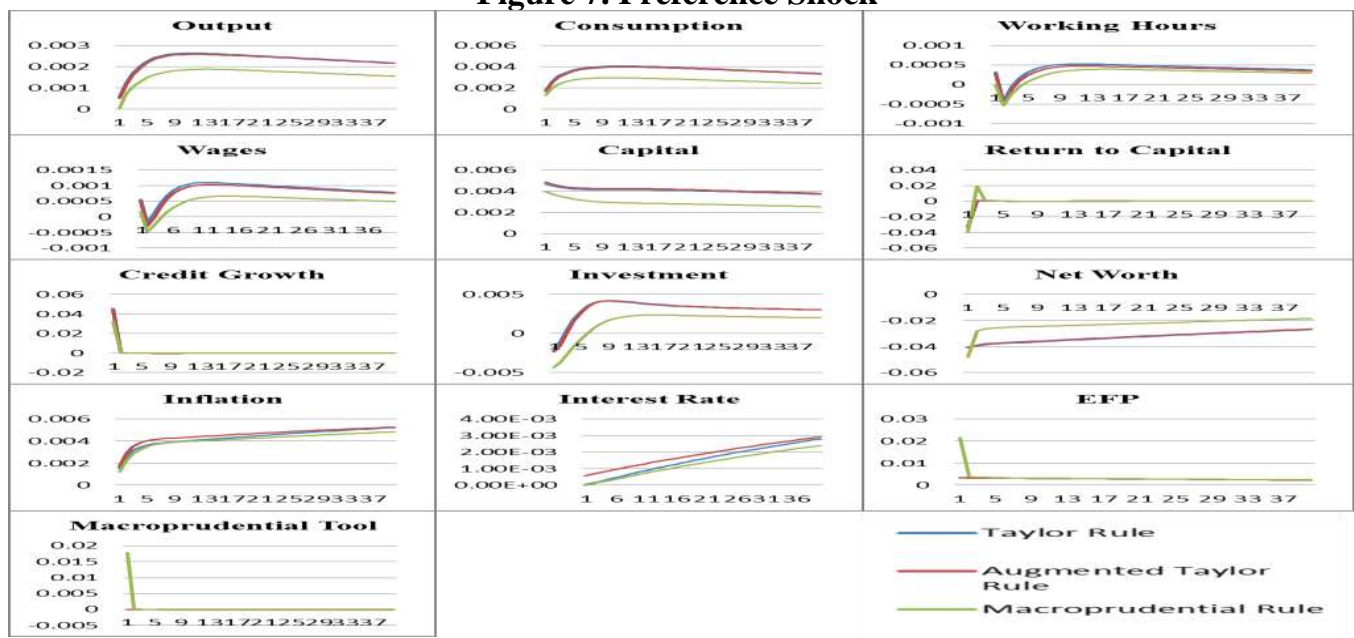

Figure 8. Investment Efficiency Shock

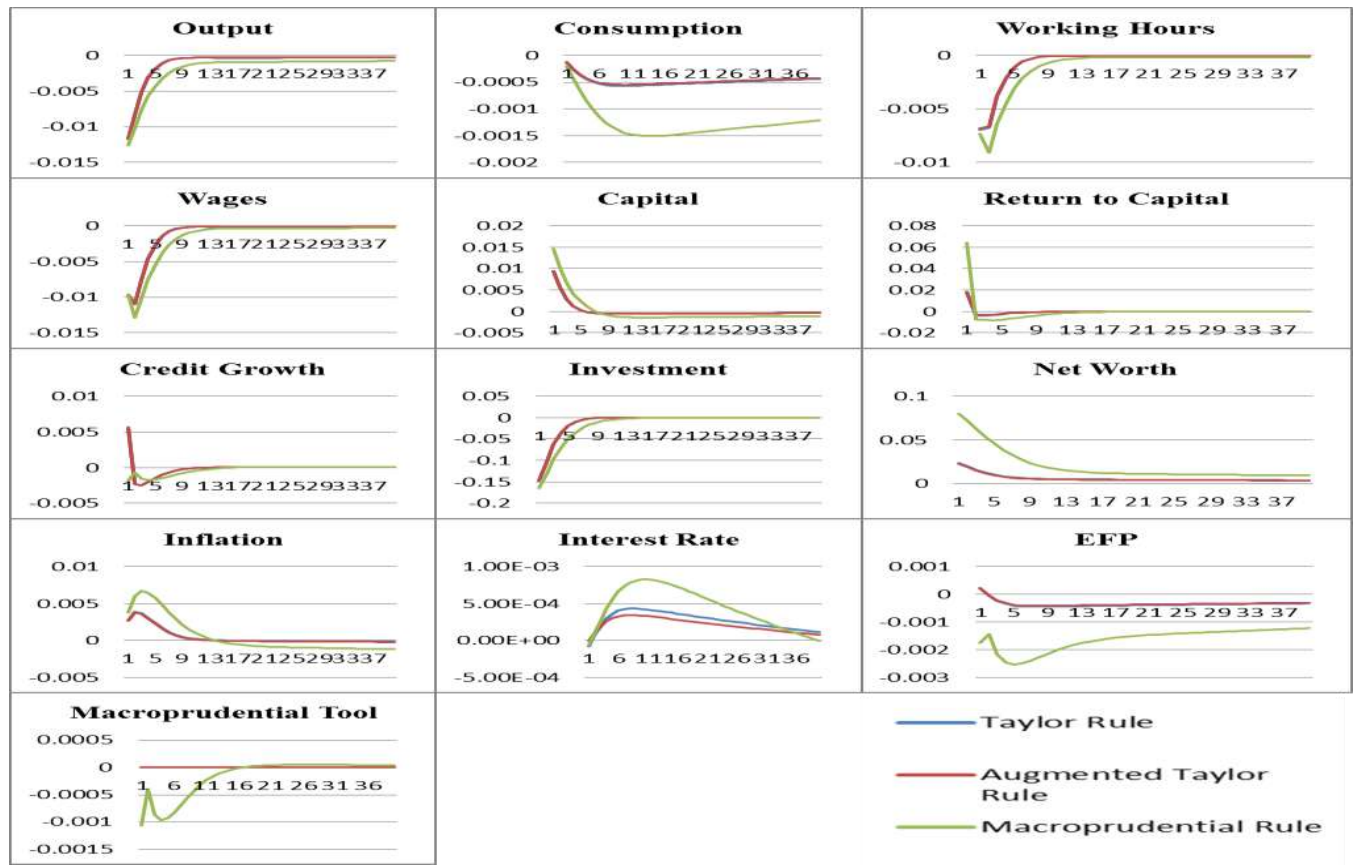

Source: Dynare Generated Output 
Finance-Growth Nexus and Relative Efficacy of Alternative Policy Regimes: An Investigation for Pakistan

Figure 9. Price Mark-up Shock

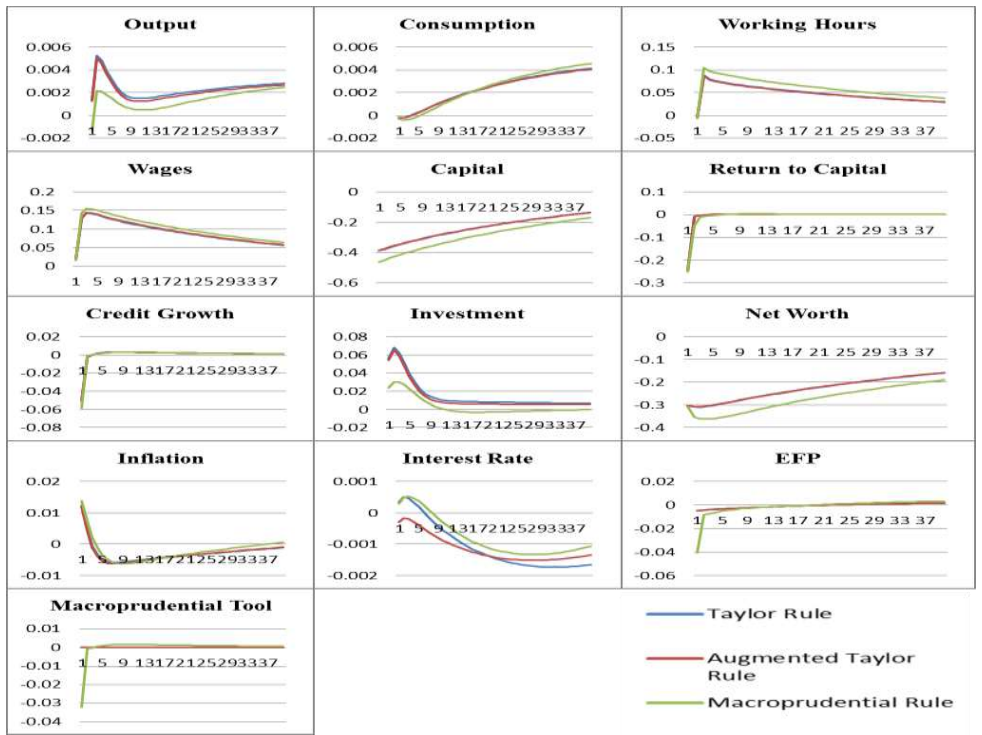

Figure 10. Wage Mark-up Shock

\begin{tabular}{|c|c|c|}
\hline $\begin{array}{rl}0.001 & \text { Output } \\
0 & \\
-0.001 & 150 \\
-0.002 & V 13172125293337\end{array}$ & \begin{tabular}{l}
\multicolumn{2}{c}{ Consumption } \\
$3.00 \mathrm{E}-04$ \\
$2.00 \mathrm{E}-04$ \\
$1.00 \mathrm{E}-04$ \\
$0.00 \mathrm{E}+00$
\end{tabular} & $0 \frac{\text { Working Hours }}{1}$ \\
\hline \begin{tabular}{ll}
0.03 & Wages \\
0.02 & \\
0.01 & \\
0 & \multicolumn{1}{l}{5913172125293337}
\end{tabular} & $0.00 \frac{\text { Capital }}{0.01}$ & $\begin{array}{r}\underbrace{}_{0.005} \\
0.005 \\
0.01\end{array}$ \\
\hline 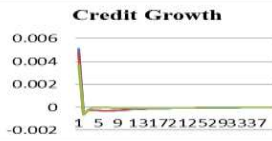 & $\begin{array}{c}0 \\
-0.01 \\
-0.02 \\
-0.03\end{array}$ & 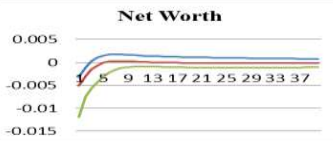 \\
\hline $\begin{array}{rl}0.0005 & \text { Inflation } \\
0 & \\
-0.0005 & 1 / \sqrt{111621263136} \\
-0.001 & \sqrt{0.0015} \\
-0.002 & \end{array}$ & 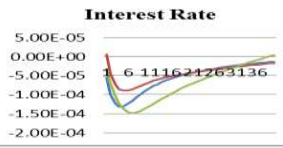 & $\begin{array}{r}0.003 \\
0.002 \\
0.001 \\
0\end{array}$ \\
\hline \begin{tabular}{l|l}
\multicolumn{2}{l}{ Macroprudential Tool } \\
0.003 \\
0.002 \\
0.001 & \\
0 & \\
& 15913172125293337
\end{tabular} & & $\begin{array}{l}\text { Taylor Rule } \\
\text { Augmented Taylor } \\
\text { Rule } \\
\text { Macroprudential Rule }\end{array}$ \\
\hline
\end{tabular}

Source: Dynare generated output 